\title{
胃癌根治手術における術中胃動脈内 制癌片注入法に関する研究
}

\author{
佐 藤 和 徳
}

群馬大学医学部第二外科学教室（主任 藤森正雄教授）

\section{I 緒 言}

近年, 胃癌に対してレ線造影，内視鏡検查，胃集団 検診など早期発見, 早期治療への努力がつみかさねら れている。乙のためかっては偶然にしか発見され得な かった早期胃癌, 微小胃癌が発見されるようになり,そ の治裺の面にも明るい見通しがもたれるようになった しかしながら乳癌, 子宮癌などの場合とは異って, そ の診断技術ならびにその実施方法にはなお多くの困難 な問題が残されていると思われる．従って，単に早期 診断, 早期治療の方式を推進するだけで胃癌の治療成 績を現在より大幅にひきあげることは至難である，換 言すれば，ある程度進行した胃癌に対しても，有効な 治療法がない限り, 治療成績を現状より著しく向上さ せるととは困難と思われる。

現在, 胃癌の治療は手術が最良の方法であることは 論を俟たないが，諸家の根治手術成績たとえば 5 年生

表 1 胃癌根治手術成績

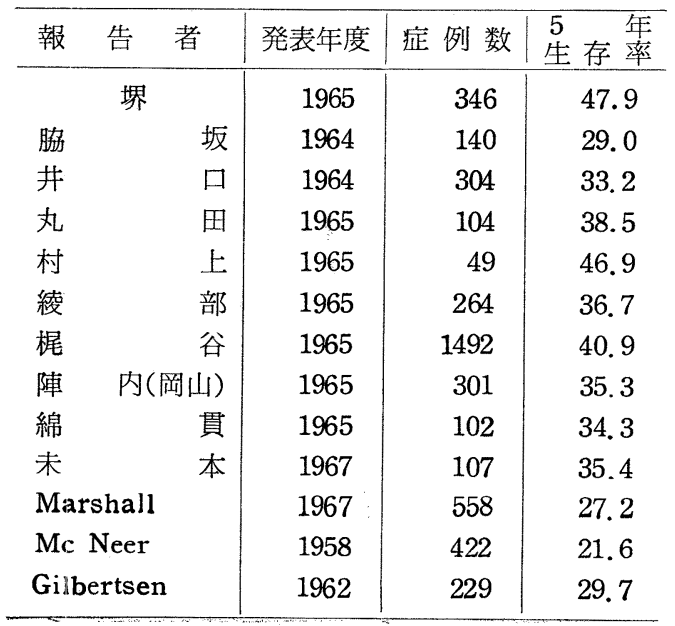

存率をみると, 表 1 の如く手術術式の拡大, 改善にと もない漸次その成績の向上がみられるものの(1 4)，い まなお50\%に満たない現状である。

手術手技に関しては，麻酔などの進歩に伴い，転移 リンパ節の徹底的郭清を意図した拡大根治手術が行わ れるようになったが，長時間の手術操作により癌細胞 撒布を促すおそれがあり，また肉眼的な郭清手術には 自から限界があるものと思われる。

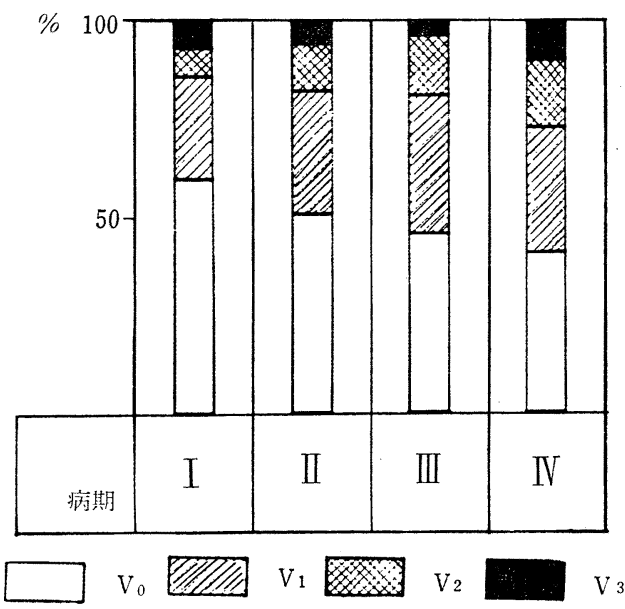

図 1 臨床病期と血管内侵入

教室の症例について，胃癌取扱い規約6)を基にして 臨床病期及び胃壁深達度と癌細胞血管内侵入像との関 係をみると，図 1，2の如く，臨床病期が進むにつれ Vascular Invasion（V.I）が増加し，また胃壁深達 度が進むにつれてV.I が増加することが認められた。

また同一病期及び同一深達度の胃癌では，当然のこ とふがら血管内侵入陽性症例の予後が悪かった。

このように手術中の癌細胞撤布，血管内侵入，潜在 性肝転移, 胃壁内転移などの癌のとり残しによる術後 再発の諸要因を考慮すると，何らかの補助療法の必要 


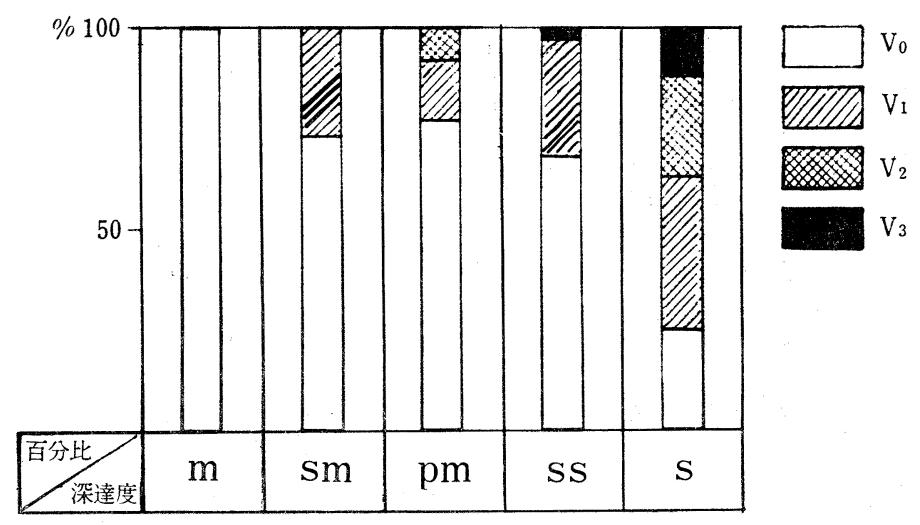

図 2 羿壁深達度と血管内侵大

性を痛感させられる。乙の立場から著者は根治手術と 化学療法を併用して, 治療成績を向上させることを意 図したのである。Adjuvant Chemotherapy とし て制癌剂を使用する場合に，その使用方法が問題とな るが，局所投与法は腫瘍細胞に対して高濃度の制癌剤 を作用せしめ，しかも全身に対する悪影響を軽減する という意味で優れた方法であると思われる。

著者は, 胃癌根治手術に合併して術中胃動脈内に制 癌剤を注入する方法を試み若干の知見を得たので報告 する。

\section{II 制癌剂胃動注法の術式と適応}

本法を実施する場合にその術式について述べると， 図 3 如くまず癌腫より比較的はなれた胃大網動脈より Polyethylene Tube の Cannulation を行なう.つ いで短胃動静脈を除くすべての胃の動静脈を次々に遮
断し, カニューレより色素（エバンスブルー）を注入 して癌腫及びその周辺が着色するのを確認した上で, 教室考案の持続動注ポンプ (図 4) を用いて, Mitomycin C (以下M. M. C. と略す) を10〜20mg (0.2〜 $0.4 \mathrm{mg} / \mathrm{kg}$ ) $500 \mathrm{ml}$ の生理的食塩水に溶解して, 約 10〜15分間で注入する.

5-FUを使用する場合には500～1000mg (10～20mg/ $\mathrm{kg}$ をやはり生理的食塩水 $500 \mathrm{ml}$ に溶解して注入を行 なう。

本法の主な適応症例は,やや進行した胃癌例えば胃 癌取扱い規約6)の Stage II, III 根治手術との併用 であるが，姑息手術と合併して本法を試みた症例もあ る.

しかし本法を適用する際に，原則としてあまり高粭 でなく, 術前の血液及び肝機能, 腎機能に障害の認め られないか,あるいは軽度のものを選び, Total Gastrectomy を施行せざるを得ない症例は避けている.

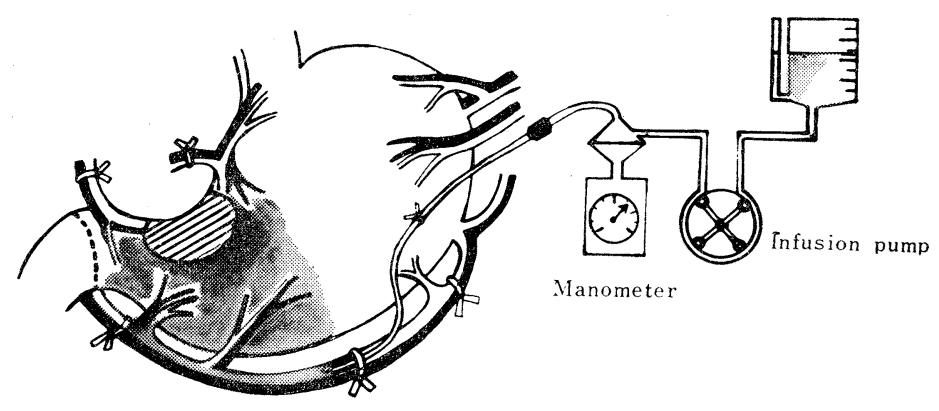

図 3 Schema of Gastric Arterial Infusion 


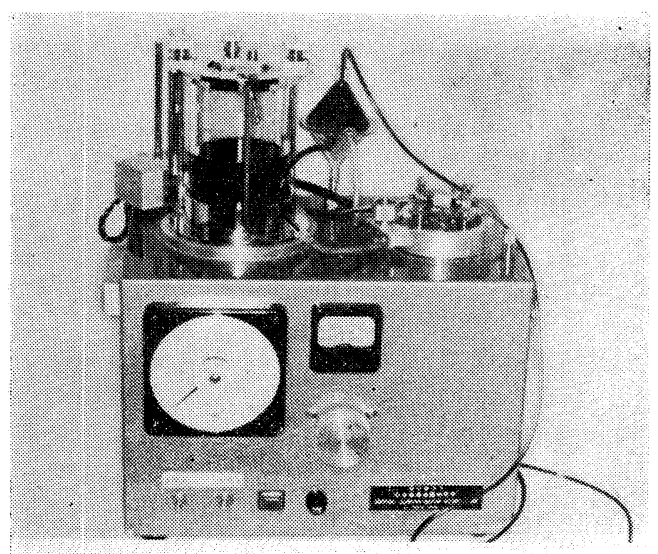

図 4

\section{III 動物実験編}

\section{a）胃動脈内注入実験と血流遮断}

1) 実験目的

胃では動脈系も静脈系も粘膜下で網状に豊富な吻合 すなわち血管網を形成しているので，一本の動脈より 制癌剤を注入する場合に，動脈相瓦間の粘膜下吻合を 通じてできる逆流圧という問題がある。そこでいかれ すれば比較的低い注入圧で制癌剤を広範囲に作用させ ることができるであううかと考光，次のモデル実験を 行なった.

2）実験材料及び方法

健康雑種成犬（体重10 15kg） を用いて，ポリ工 チレンカテーテルを左胃動脈活管した後に, 色素液 (トルイヂンブルー $100 \mathrm{mg} / \mathrm{dl})$ を注入して，血管遮 断と着色範囲との関係を検討した。 （j）捰管に用いた左胃動脈以外の血管はすべ て開存せしめる.

（ii）左胃動脈以外は左胃静脈のみを遮断し て，他の血管はすべて開存せしめる.

（iii）短胃動静脈以外のすべての動静脈を遮断 する。

（iv）短胃動脈以外の動脈党遮断する。

（v）左胃静脈遮断记短胃動脈以外の動脈遮断 を併用する。

この場合の逆流圧を Manometer を接続して測定 した.

\section{3）実験成績}

同一注入圧における着色範同を検討すると短胃動脈 以外のすべての動脈を遮断した場合が最も広く、つい で短胃動静脈を除くすべての動静脈を遮断した場合， 左胃静脈のみ遮断した場合, 他の血管はすべて開存し ている場合の順であった。

次に逆流圧の変動を測定した結果, 動静脈を遮断す ると逆流圧は下降し，動脈の久を遮断すると更に圧は 下降するととが認められた。（図 5，6）

\section{b） $\mathrm{MMC}$ 接触腹水肝癌（in vitro）の 脾内注入実験}

1)

胃動注法を実施する際に，注入制癌剤はどの程度の 濃度及びぞの程度の接触時間が必要であるかというと とは大きな問題であるが，実験的に胃癌を作成するこ とがかなり困難なことと, 実験腫瘍とヒトの癌では, 癌細胞の制癌剤に対する感受性が必ずしも同一でない

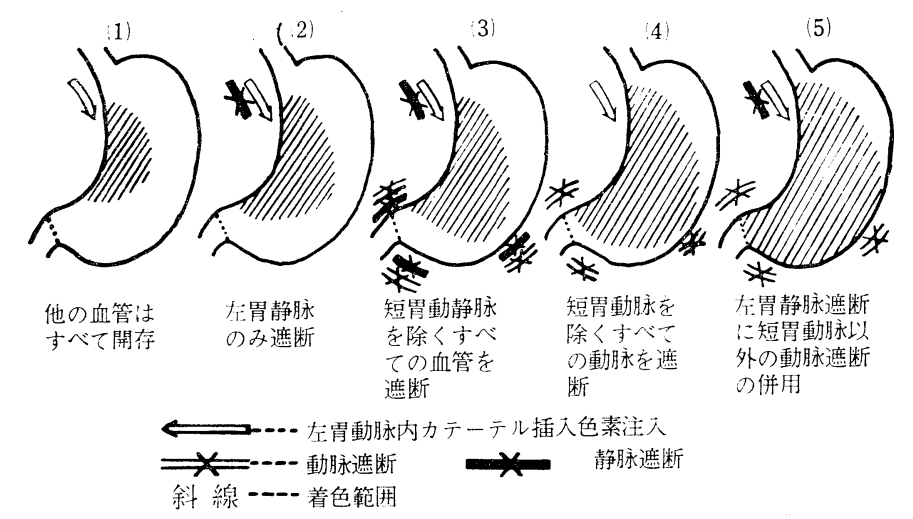

図 5 血流遮断と着色範用 
胃癌根治手術における術中歕動脈内制癌郕注入法

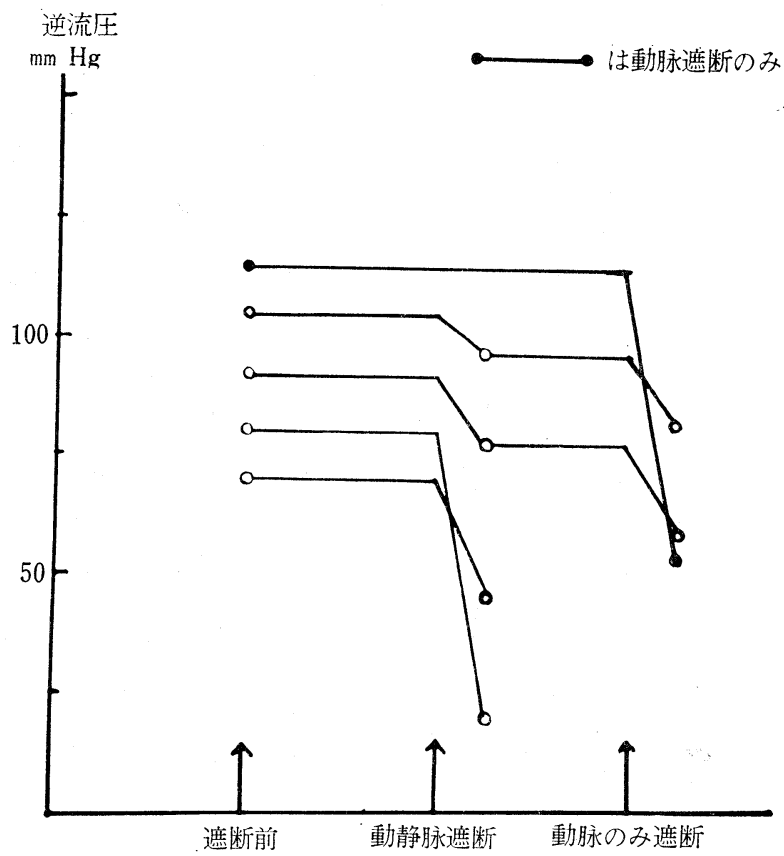

図6 左胃動脉捙管時における逆流圧の変動

表 2 Mitomycin C 接触腹水肝癌（in vitro）の脾内注入実験 実験腫痬：A H7974

実験動物：ウィスター系ダイコクネズミ

\begin{tabular}{|c|c|c|c|c|c|}
\hline \multicolumn{2}{|c|}{$37^{\circ} \mathrm{C}$ 静 置 } & 験 & $\begin{array}{l}\text { 脾 内 } \\
\text { 注 入 }\end{array}$ & 脾内注入後 $7 \sim 13$ 日目 & $\begin{array}{l}\text { 所 見 } \\
7 \sim 13 \text { 日目 }\end{array}$ \\
\hline $\begin{array}{l}\mathrm{MMC} \\
\quad \begin{array}{c}\text { 濃度 } \\
(\gamma / \mathrm{ml})\end{array}\end{array}$ & $\mid \begin{array}{c}\operatorname{MMC}(\gamma) \\
/ \text { 細胞 } \\
10^{6} \text { 個 }\end{array}$ & $\begin{array}{c}\text { 接触時間 } \\
\text { (分) }\end{array}$ & $\begin{array}{l}\text { 細胞数 } \\
\left(\times 10^{4}\right)\end{array}$ & \begin{tabular}{|c} 
腹水癌実験群 \\
(対照群)
\end{tabular} & $\mid \begin{array}{c}\text { 肝転移実験群 } \\
\text { (対照群) }\end{array}$ \\
\hline 20 & 0.8 & $\begin{array}{c}1 \\
5 \\
10\end{array}$ & 500 & $\begin{array}{ll}6 / 6 & (3 / 3) \\
5 / 6 & (5 / 6) \\
0 / 6 & (5 / 7)\end{array}$ & $\begin{array}{ll}5 / 6 & (3 / 3) \\
4 / 6 & (4 / 6) \\
0 / 6 & (4 / 7) \\
\end{array}$ \\
\hline 40 & 1.6 & $\begin{array}{c}1 \\
5 \\
10\end{array}$ & 500 & $\begin{array}{ll}3 / 3 & (4 / 4) \\
1 / 5 & (3 / 3) \\
0 / 5 & (3 / 3)\end{array}$ & $\begin{array}{ll}1 / 3 & (2 / 4) \\
1 / 5 & (3 / 3) \\
0 / 5 & (2 / 3)\end{array}$ \\
\hline 60 & 0.5 & $\begin{array}{c}5 \\
10\end{array}$ & 1000 & $\begin{array}{l}1 / 6(5 / 5) \\
0 / 5 \quad(5 / 5)\end{array}$ & $\begin{array}{l}0 / 6(4 / 5) \\
0 / 3(1 / 3)\end{array}$ \\
\hline 80 & 1.0 & $\begin{array}{c}5 \\
10\end{array}$ & 1000 & $\begin{array}{l}1 / 5 \quad(5 / 5) \\
0 / 5 \quad(4 / 5)\end{array}$ & $\begin{array}{l}1 / 5(4 / 5) \\
0 / 5(3 / 5)\end{array}$ \\
\hline 100 & 4.0 & $\begin{array}{l}1 \\
5\end{array}$ & 500 & $\begin{array}{l}2 / 4 \quad(5 / 5) \\
0 / 5 \quad(4 / 5)\end{array}$ & $\begin{array}{l}3 / 4 \quad(5 / 5) \\
0 / 5(2 / 5)\end{array}$ \\
\hline
\end{tabular}


などの点より，ての問題を実験的に解明することは非 常に困難である。

胃動注を行なうと胃壁血管内の血液は間もなく制癌 剤で置渙されるので，かり亿手術操作中胃壁血管内よ り門脈系に流出してきた癌細胞は一度制癌剂と接触し てから撒布されたてとになる。乙れを模型的㲹考える と，一度制癌剤と接触した後に門脈系江流入するのと 同じことになる。そこで次のようなモデル実験を試み た.

\section{2）実験材料及び方法}

実験動物として Wistar 系大黑ネズミ（雄, 体重

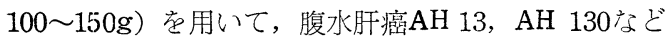
より抗癌剤化対する感受性が低いといわれる腹水肝癌 AH 7974t，シリコンコーティングした試験管内で $20 ， 40 ， 60,80,100 \mu \mathrm{g} / \mathrm{ml} \mathrm{MMC}$ と $15 ， 10$ 分間接触 させた後に, 生理食塩水でよく洗浄して健常Wistar 系大黑ネズミの脾内に注入し， $7 〜 13$ 日後に剖見して 腹水癌及び肝転移の形成率を検討した。 この際の $\mathrm{AH}$ 7974 の細胞数は500〜1000 コ/mlである.

\section{3）実験成績}

表 2 の如く, $20 \mu \mathrm{g} / \mathrm{ml}$ の濃度のMMCを接触させた 場合に, 1 分及び 5 分間接触では対照とほぼ同様の転 移率を示すが，10分間接触させると対照群の肝転移率 $4 / 7$ 亿対し0/6を示し, 腹水癌も $0 / 6$ (対照群 $5 / 7$ ) の発 生率であった。

$40 \mu \mathrm{g} / \mathrm{ml}$ 接触させた場合には， 5 分間接触で肝転 移率 $1 / 5($ 対照 $3 / 3)$ ，腹水癌は $1 / 5 （$ 対照 $3 / 3 ）$ を示し ている.

$80 \mu \mathrm{g} / \mathrm{ml}$ を接触させると, 5 分間接触 $1 / 5$ (刘照 $4 / 5$ ) の肝転移率を示した。

すなわち, $20 \mu \mathrm{g} / \mathrm{ml}$ 以上の濃度のMMCを10分間接 触させ机ば，肝転移及び腹水癌の発生を抑制し得るて とが認められた。

\section{c）胃動注実験における犬の血液，畈機能所見}

1）実験目的

高濃度に注入された制癌剤は門脈及び肝を通過する 際に，稀橎あるいは不活性化されることが考光られ正 常肝細胞を障害する。

まだ，末梢血中の MMC が骨髄系に対してどのよう な影響を与えるか, 接触実験で得た注入濃度, 量が適 当であるか否かを検討すべく末梢血，肝機能を検査し た。
2）実験材料及び方法

体重約 $15 \mathrm{~kg}$ の健康雑種犬を開腹後, 胃切開術を施 し，同時に胃大網動脈に插管したカテーテルから $\mathrm{MM}$ Cを動注した。

実験動物：健康成大

使用薬剤：マイトマイシンC

（1）対照（胃切開のみ）

2 頭

(2) $0.2 \mathrm{mg} / \mathrm{kg}(20 \mu \mathrm{g} / \mathrm{ml})$ 動注十胃切開 3 頭

(3) $0.4 \mathrm{mg} / \mathrm{kg}(40 \mu \mathrm{g} / \mathrm{ml})$ 動注十胃切開 3 頭

(4) $0.8 \mathrm{mg} / \mathrm{kg}(80 \mu \mathrm{g} / \mathrm{ml})$ 動注十胃切開 6 頭 $(4 \sim 1)$ : 急速注入群 $(5 \sim 8$ 分） 3 頭 $(4 \sim 2)$ : 低速注入群（15分） 3 頭

\section{図 7 胃動脈内制癌剂注入実験}

これらについて末梢血を術前, 術後 $2,5,7,10$ 日に採血して 赤血球数, 白血球数, 血小板数を計測 し, 肝機能を術前, 術後 5, 10 日に検査した.

3）実験成績

i）血液所見 : MMC $0.8 \mathrm{mg} / \mathrm{kg}(80 \mu \mathrm{g} / \mathrm{ml})$ を
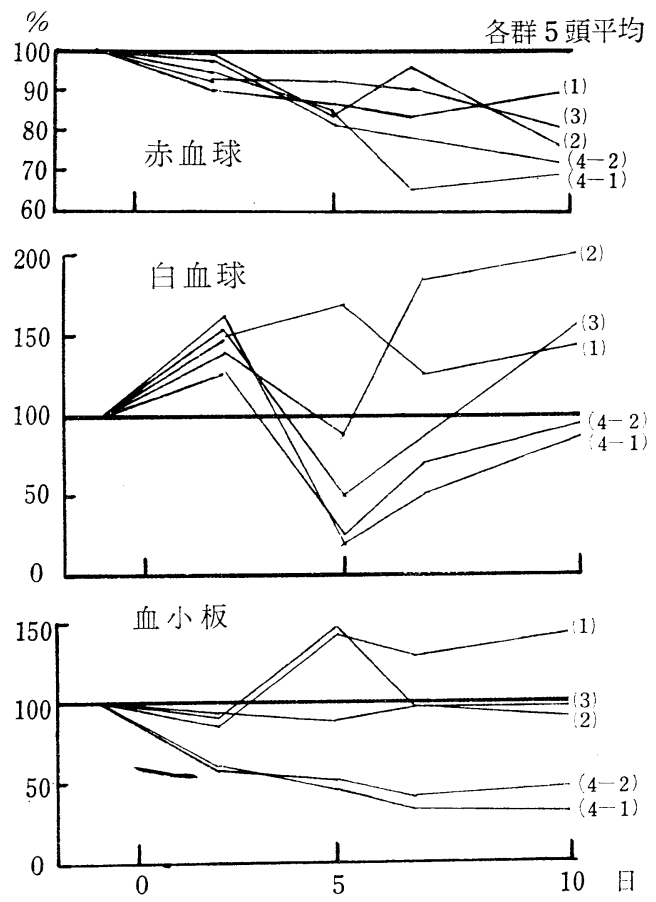

図 8 胃動注後の血球戊分の変動（犬） 
急速注入したもの 3 頭中，1頭は副障害のために死亡 した．図 8 の如く術前值を $100 \%$ とて末梢血の変動 を表示すると, 赤血球数は術後減少してくるが, 殊に $0.8 \mathrm{mg} / \mathrm{kg}$ 注入群で著明であった。 $0.4 \mathrm{mg} / \mathrm{kg}$ 注入群 では対照群と比較して赤血球減少率は著明ではなかっ た.

白血球数は一般に術後 2 日，3 日に上昇し 5 日頃か ら減少してくる。 $0.8 \mathrm{mg} / \mathrm{kg}$ 注入群では $50 \%$ 以下を 示すが， 7 日，10日には再び增加してくる．殊に0.4 $\mathrm{mg} / \mathrm{kg}$ 以下では10日には対照群との差はなくなる。

栓球数は術後 2 日，3 日で減少してくるが $0.4 \mathrm{mg}$ 以下では術後10日でほぼ術前值と等しい值を示すのに 反し, $0.8 \mathrm{mg} / \mathrm{kg}$ 注入群で遷延する栓球減少症がみら れる。

ji）肝機能所見：B.S.P值はMMC $0.8 \mathrm{mg} / \mathrm{kg}$ 注 入群で術後 5 日目に上昇しているが，死亡例を除いて 術後 10 日に注ほ修前值に回復した。 $0.4 \mathrm{mg} / \mathrm{kg}$ 以下 では特て変動はない. Alkali Phosphatase值（Bodanski単位) は, $0.8 \mathrm{mg} / \mathrm{kg}$ 注入群以外では正常範囲 内の変動を示したが， $0.8 \mathrm{mg} / \mathrm{kg}$ 急速注入群は術後 5
日に, 7.0 Bodanski unitを示した。

GOT值は死亡例を除いた $0.8 \mathrm{mg} / \mathrm{kg}$ ・急速注入群で 術後 5 日は74単位と上昇し, 術後 10 日には61単位とや や下降するものの高值を示した.

$0.4 \mathrm{mg} / \mathrm{kg}$ 注入群以下は，6〜40単位以内の正常範 楝内の変動にとどまった. GPT值は $0.8 \mathrm{mg} / \mathrm{kg}$ 急速注 入群では術後 5 日目に 62 単位と高值を示したが， 0.4 $\mathrm{mg} / \mathrm{kg}$ 以下では10 30 単位内での変動を示すにすぎ なかった。

つまり．肝機能では0. $8 \mathrm{mg} / \mathrm{kg}$ 急速注入群以外は軽 度の一過性障害をみるのみであった。（図 9 )

\section{d）胃動注実験における血中濃度}

1) 実験目的

胃動脈より高濃度に注入された制癌剤は, 胃壁血管 内でプールされた後に, 門脈, 肝を経て全身血中に移行 する, この時の濃度, 殊に末梢血中濃度は癌細胞への 抑制作用とともに副作用と密接な関係をもつと思われ るので血中濃度の変動をモデル実験で追求した。

2）実験材料及び方法

健康雑種成犬を開腹し, 胃大網動脈に捙管した動脈
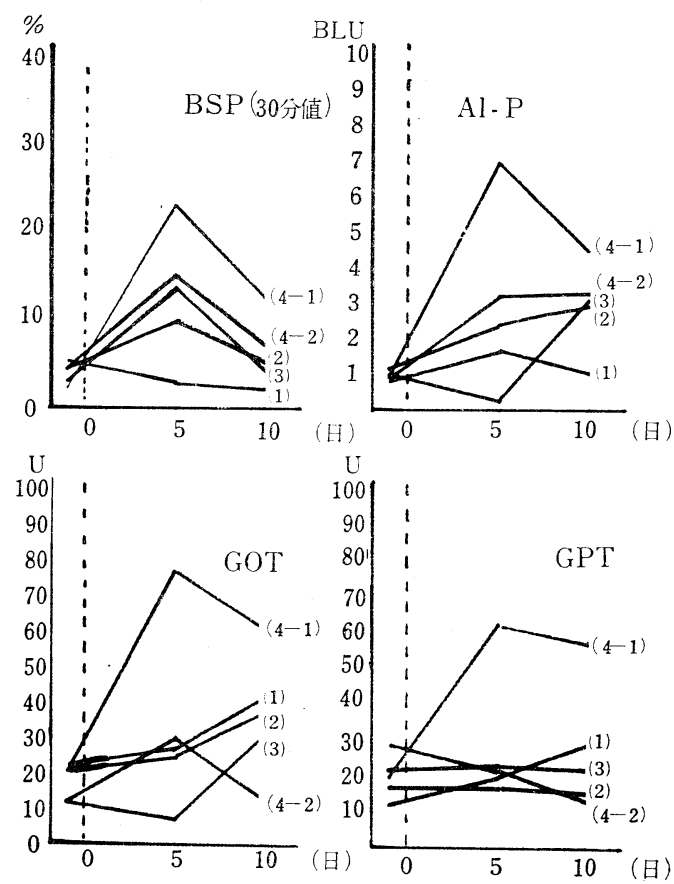

図 9 刑動脈内制癌剤注入実験 
カテーテルより MMC を $0.6 \mathrm{mg} / \mathrm{kg}$, 及び $0.4 \mathrm{mg} / \mathrm{kg}$ を各 5 頭に動注し, 経時的に閒脈血, 肝静脈血, 大腿 静脈血を採血してbioassayを行った，MMCのbioassay に関しては, 原田7), 宮村8) らの方法があるが, 実用性々敏感度の点から宮村氏の E, coli B株を使用 する薄層微量定量法を採用した。

$E$, coli B 亿対して既知濃度 MMC のつくる阻止円 の大きさを標準対数曲線にて表示しておき検体の阻止 円直径（3 検体の平均值）を同一平板上の既知濃度の MMC の阻止円直径で補正して, 検体の濃度を測定し た.

この方法で $0.0001 \mu \mathrm{g} / \mathrm{ml}$ 微量濃度まで測定するこ とができる.

\section{3）実験成績}

（i ） MMC $0.6 \mathrm{mg} / \mathrm{kg}$ ・動注群：乙の群 5 頭の 平均值をグラフで示すと, 閒脈血中濃度は動注開始直 後から上昇しはじめ, 動注終了直後に最高值 $1.1 \mu \mathrm{g} /$ $\mathrm{ml}$ 示すが, 動注終了後 15 20分で $0.25 \mu \mathrm{g} / \mathrm{ml}$ とな り速やか降し消失する.肝静脈血中濃度は動注終 了時に最高值 $0.41 \mu \mathrm{g} / \mathrm{ml}$ 示し徐々に下降する.

大腿静脈血中濃度も動注終了時汇最高值 $0.23 \mu \mathrm{g} / \mathrm{ml}$ を示す, が動注終了後 15 分で $0.05 \mu \mathrm{g} / \mathrm{ml}$ と下降し約 2 時閒後には血中から検出され得なかった.

(ii) $\mathrm{MMC} 0.4 \mathrm{mg} / \mathrm{kg} \cdot$ 動注群: $0.6 \mathrm{mg} / \mathrm{kg}$ 群 とほぼ同様の傾向を示し, 門脈血中濃度は動注終了直 後你最值 $1.0 \mu \mathrm{g} / \mathrm{ml}$ を示し, 大腿静脈血中濃度は

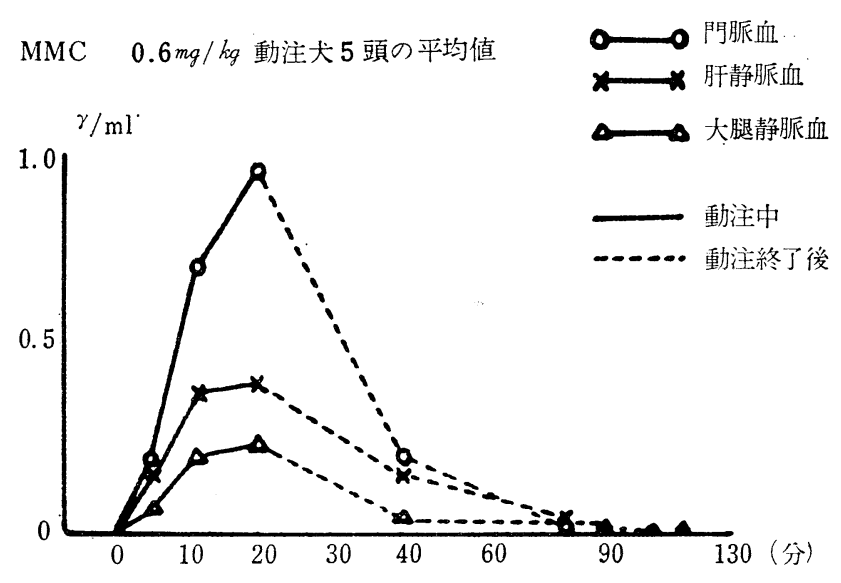

MMC $0.4 \mathrm{mg} / \mathrm{kg}$ 動注犬 5 頭の平均值 $\gamma / \mathrm{ml}$

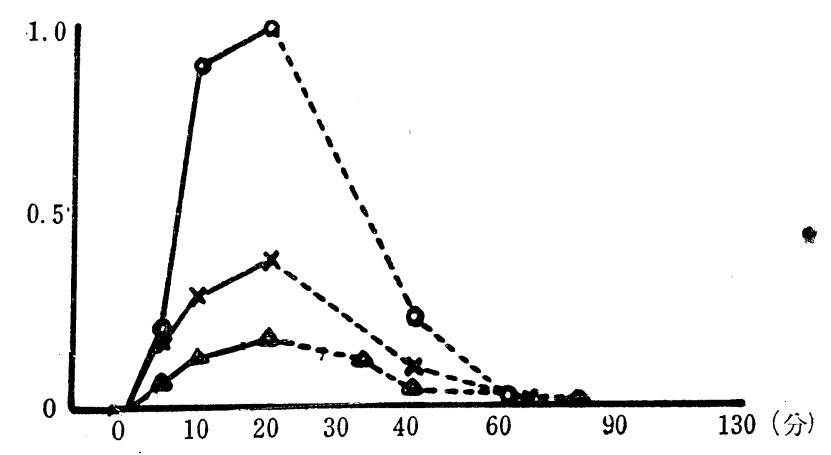

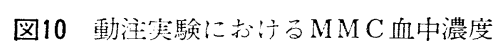


動注終了後90分で，ほとんど検出するてとができなか った.

\section{e）制癌剤注入胃腸壁の組織学的検索}

1）実験目的

臨床例で胃動注法により注入された制癌剂が正常胃 腸壁を障害して胃腸吻合部の瘾合不全の原因となって はならないが，乙れを検討すべくモデル実験で得た胃 腸壁を光学顕微鏡的に検索した。

2）実験材料及び方法

体重約 $15 \mathrm{~kg}$ 健康雑種成犬を開腹し, 胃大網動脈ま たは腸間膜動脈より，あらがじめエバンスブルーを注 入して動脈の交配領域を確認した後に，下記の如く各 濃度のMMC を動脈内に注入してその部の胃腸壁に目 標を残して閉腹する。

術後 5 日, 10 日に再開腹して動注部及び非動注部の 胃及び腸壁を剔出して，10\%フォルマリン溶液で固定 後 Haematoxylin-Eosin 染色して光影学的倹討し た.

(i ) $20 \mu \mathrm{g} / \mathrm{ml} \mathrm{mMMC} 100 \mathrm{ml}$ 動注（6 頭)

( 6 頭のうち 3 頭は術後 5 日に再開 腹 し, 残りの 3 頭は術後 10 日目汇再開腹す る。以下同様である。

(ii) $40 \mu \mathrm{g} / \mathrm{ml}$ MMC $100 \mathrm{ml}$ 動注 (6 頭)

(iii) $60 \mu \mathrm{g} / \mathrm{ml}$ MMC $100 \mathrm{ml}$ 動注（6頭)

(iv) $80 \mu \mathrm{g} / \mathrm{ml}$ MMC $100 \mathrm{ml}$ 動注（6 頭) （v） $100 \mu \mathrm{g} / \mathrm{ml}$ MMC $100 \mathrm{ml}$ 動注（6 頭)

\section{3）実験成績}

$100 \mu \mathrm{g} / \mathrm{ml}$ 注入群では 6 頭のうち 3 頭が術後死亡し た. $80 \mu \mathrm{g} / \mathrm{ml}$ 注入群で術後 5 日, 及び 10 日の動注腸壁 をみると, 非動注腸壁と比較して, 浮腫, 血栓, 変性 壊死, 細胞浸潤などの病理組織学的な変化を認めるこ とはできなかった， $60 \mu \mathrm{g} / \mathrm{ml}$ 以下でも同様に変化を 見出すととはできなかった。

\section{f) 小括}

左胃動脈内のカニューレから制癌剤を注入する場合 そ，左胃静脈と短胃動脈以外の動脈をすべて結紫する と, 最大の着色範囲が得られて逆流圧も下降するので 注入圧を多少下げても制癌凨がよく行きわたることが わかった。

また左胃大網動脈に挿管して同様な操作を行なった 場合も着色範囲は左胃動脈找管の場合とほぼ同様の成 績が得られた。しかしながら実際に臨床例で胃切除術 を施行する場合にはポりエチレンチューブ挿管時の癌 腫に対する機械的刺激を避けるためと，手技の容易さ から, 癌腫から比較的離れた動脈より捙入した上で癌 腫に近ずけた方が有利であると考光，通常主として右 胃大網動脈よりCannulation在行なっている。また動 脈のみを遮断する操作はやや繁雑であり，動静脈を同 時に遮断した場合とでは着色笔囲に大差はないので， 実施臨床で注短罢動静脈を除く他のすべての血管を遮

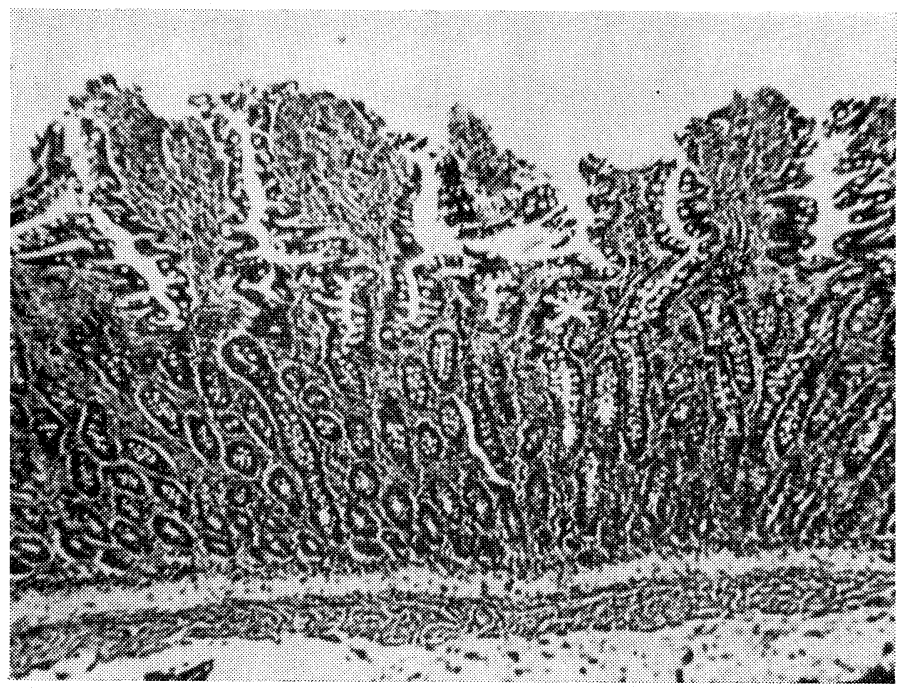

図11動注部 
(560)

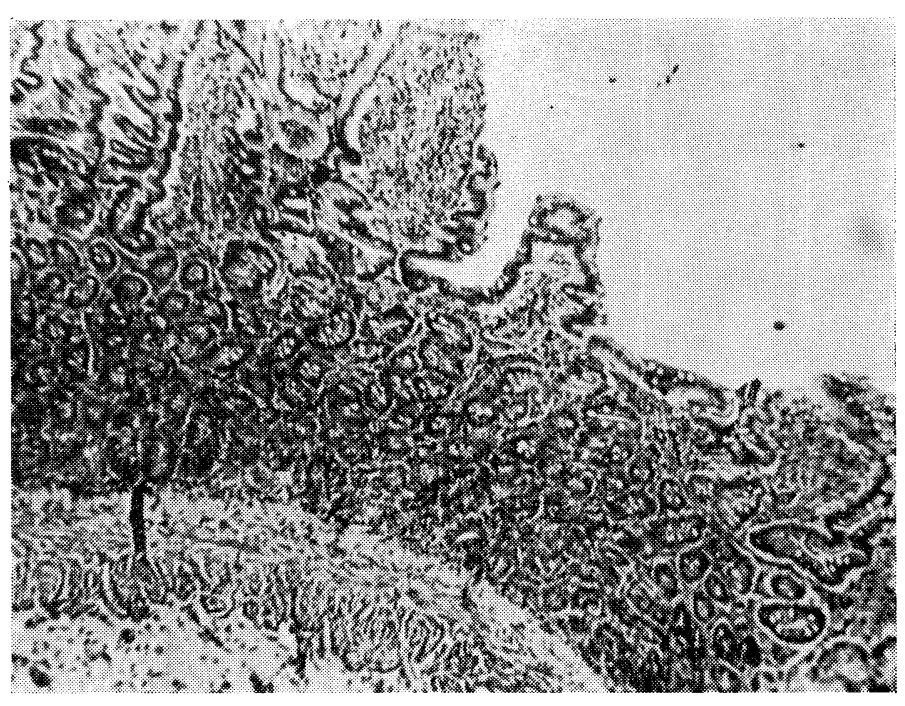

図12 非動 注 部

断しで胃動注法を行なっている.

接触実験ではMMC20 $\mu \mathrm{g} / \mathrm{ml} 10$ 分間作用させれば 肝転移を充分防止できることがわかり，一方副作用の 面から見た場合には， $\mathrm{MMC}_{0} .8 \mathrm{mg} / \mathrm{kg}(80 \mu / \mathrm{ml})$ の 投与は血液及び肝機能の障害を招来する場合がみられ るので，乙の濃度すなわち $\mathrm{MMC} 0.8 \mathrm{mg}(80 \mu / \mathrm{ml})$ 以 下の使用がよいと思われる。

てれらの実験結果に基づいて肝転移に対する有効濃 度, さらに血液ならでに肝機能に対する副作用防止を 許容し得る濃度として, 臨床例では MMC $0.2 \sim 0.4 \mathrm{~m}$ $\mathrm{g} / \mathrm{kg}(20 \sim 40 \mu \mathrm{g} / \mathrm{ml})$ を約15分間にわたって胃壁内 に動注するととにした。

\section{IV 臨床研究編}

\section{a）胃動注法の手術手技}

まず，癌腫より比較的離れた右胃大網動脈を結㮡 し, それより癌腫の存在する方向に向って動脈内てポ リエチレン管を挿入して癌腫に最も近い位置に固定す る. 次に，短胃動静脈を除くすべての胃の血管を順時 遮断守る。

血流遮断が完了したら, 教室考案の注入装置を用 い，注入圧を観察しつつ制癌剤を注大するが，通常20 $\mu \mathrm{g} / \mathrm{ml}$ のMC0.2〜0.4mg/kgを15分間にわたって動 注し, 動注開始後直ちに大小網㔀離切除を進めてい

る。

\section{b）胃動注法を適用した臨床症例}

群大第二外科教室における胃癌総症例は表 3 の 如 く, 1954年 5 月から 1969年月 2 末までに 373 症例あり 手術率98.1\% (366/373) ，切除率77.7\%(290/373)存 示し, 治療手術の 5 年生存率は $22.5 \%(22 / 97)$ 非治凂 手術では，8.3\%(6/83) を示した。術中胃動注法を開

表 3 群馬大学第二外科等癌症例

(1954.5 1969.2)

胃癌患者総数

手術数(率)

切除数(率)

5 年生存率

$\begin{array}{cc}\text { 373例 } & \\ 366 \text { 例 } & (98.1 \%) \\ 290 \text { 例 } & (77.7 \%) \\ \text { 癒手術 } & 22.5 \% \\ \text { 療手術 } & 8.3 \%\end{array}$

表 4 治癒手術 - 非治癒手術別症例数

(1962.5 1969.2)

\begin{tabular}{c|c|c|c|c}
\hline & $\begin{array}{l}\text { abs. } \\
\text { curat. }\end{array}$ & $\begin{array}{l}\text { rel. } \\
\text { curat. }\end{array}$ & $\begin{array}{l}\text { non- } \\
\text { curat. }\end{array}$ & 計 \\
\hline 動 注 群 & 18 & 40 & 22 & 80 \\
\hline 対 照 群 & 43 & 54 & 60 & 157 \\
\hline 計 & 61 & 94 & 82 & 237 \\
\hline
\end{tabular}


始した. 1962年 5 月より1969年 2 月末までの胃癌手術 例は 237 例で, そのうち80亿動注法を補助療法として 合併施行した，(表 4)

その80例を術式別にみると絶対治癒切除は18例, 相 対治癒切除40例, 非治癒手術 22 例となっている。 また 表 5 の如く, 臨床病期別分類では, 治癒手術で動注例 は Stage I 3 例 (対照26例), Stage II 19例（対 照35例), Stage III 36 例(刘照31例)であり, 非治癒 手術で動注例は Stage III 3 例(対照17例), Stage IV 19例（対照40例）と病期の進行したものにこの胃動注 法を多く合併している.

\section{c）臨床症例の遠隔成績}

1）治癒手術成績

初期の Nitromin 少量動注例及び他病死例を除い たMMC 動注症例の治癒手術成績を検討すると, 図13 の如く長期経過例は少ないが 4 年以上経過群の 4 年生 存率は, 63.9\% (7/11) であるのに, 対照群は38.9\% (14/31) 走した.

また, 3 年以上経過群についても動注症例 3 年生存 率は66.7\%(12/18)に対して, 刘照群は44.5\%(19/40)
と動注群で良好な成績が得られている。

表 5 臨床病期別症例数

治癒手術

\begin{tabular}{l|l|l|l|l} 
& I & I & II & N \\
\hline 動 注 群 & 3 & 19 & 36 & 0 \\
\hline 対 照 群 & 26 & 35 & 31 & 5 \\
\hline
\end{tabular}

非治痛手術

\begin{tabular}{|c|c|c|c|c|}
\hline & I & II & III & N \\
\hline 動 注 群 & 0 & 0 & 3 & 19 \\
\hline 対 照 群 & 0 & 2 & 17 & 40 \\
\hline
\end{tabular}

2）臨床病期別治癒手術成績

次に, 胃癌取扱い規約に従って進行度を分類し, それ ぞれの臨床病期別の治癒手術成績を検討した，その結 果, Stage II の4年生存率は動注群で100\%(3/3), 対照群35.7\%（5/14）在示し, Stage III の動注症例の

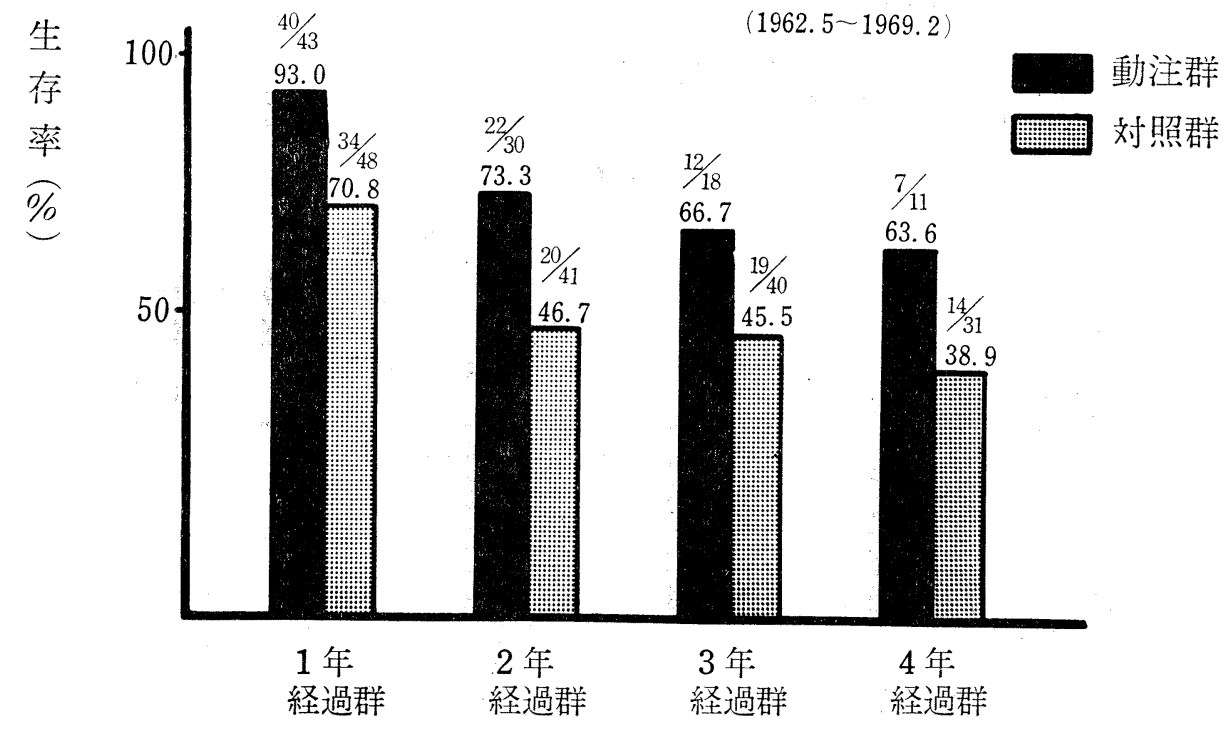

図13 治癒手術成績 
4 年生存率は，50.0\%（4/8） 亿対し対照群は $30.0 \%$ (3/10)となりやはり動注群で良いようであるが，末 だ症例数が充分でないので今後の症例について更に検 討を加えたい． 3 年以上経過群については，Stage II の動注群の 3 年生存率は $77.7 \%(7 / 9)$, 対照群 $40.0 \%$ (6/15), Stage III の動注群55.6\%(5/9), 対照群23.1 \%(3/13)であり，動注群の成績に良い結果が得られて いる.（図14）

\section{3）深達度別治痛手術成績}

胃癌取扱い規約による深達度の 分類で， $\mathrm{m} ， \mathrm{sm}$, $\mathrm{pm}$ の如き漿膜浸潤のないものでは，動注群の4 年生
存率は100\% (3/3)を示し，刘照群は，60.0\%(6/10) となっている．深達度 $\mathrm{pm}$ までの $1 \sim 3$ 年経過群の動 注症例の生存率は症例数が少ないが，いずれも $100 \%$ を示すのに対し，対照群では70\%強を示した。

ss, s 群の如き深達度の高いものでは, 動注症例の 4 年生存率 $50.0 \%$ (4/8), 対照群 $38.1 \%(8 / 21)$ を 示し， 3 年生存率は動注症例 $53.8 \%(7 / 13)$, 対照群 $33.3 \%(8.24)$ という結果を得ており，動注群にやや良 好な成績が得られている。（図15）

\section{4）リンパ節転移と治瘺手術成績}

リンパ節転移の有無で動注症例を対照群と比較する

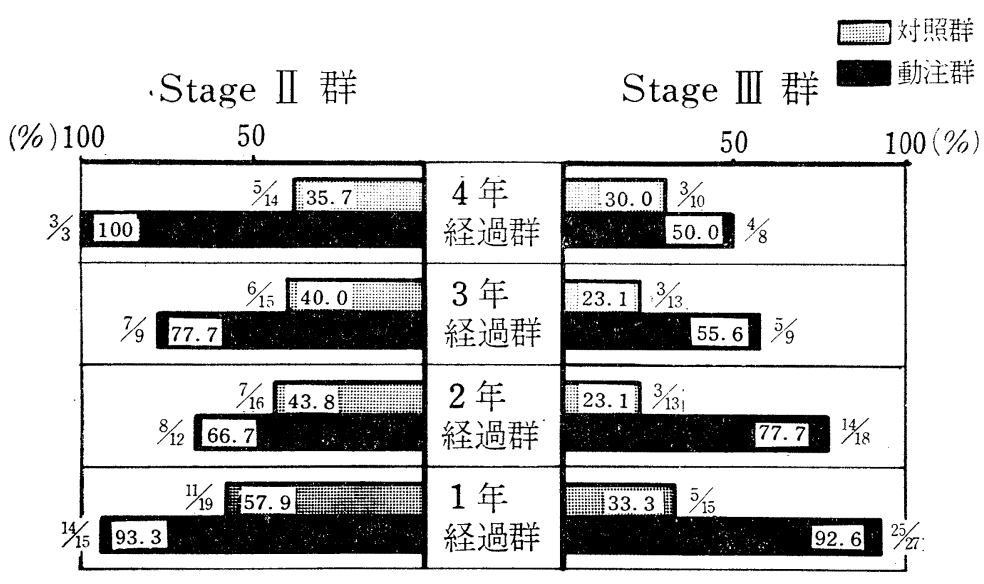

図14 Stage と治癒手術成績

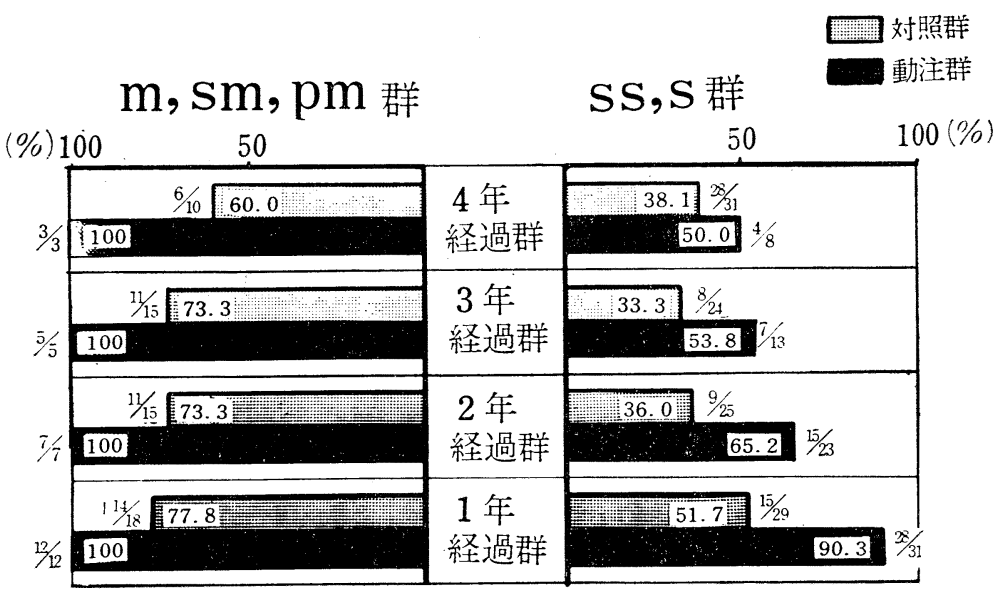

図15 深達度と治癒手術成績 
と・リンパ節転移陰性例の如き比較的早期の胃癌に胃 動注法を適応した症例が少なく有意差はないが，転移 陽性例の 4 年生存率では動注群 $60.0 \%(6 / 10)$ で，対 照群 $28.6 \%$ (6/21) に比して極めて良好である。また 3 年生存率も動注群 $75.0 \%$ (12/16), 対照群 $29.2 \%$ (7/24)で明らかく動注群で良い成績を示した（図16）

5）血管内侵入之治痖手術成績

胃癌取扱い規約の血管内侵入の有無を組織学的に検 索し, その有無により両群の手術後成績を比較した。 血管内侵入陰性例では動注群の 4 年生存率は $66.7 \%$ $(4 / 6)$, 対照群は $45.0 \%(7 / 20)$ を示し, 3 年生存率
では動注群90.9 (10/11), 対照群53.8（14/26)であっ た.

血管内侵入陽性例では 動注群の 4 年生存率 $60.0 \%$ $(3 / 5)$, 対照群 $45.5 \%(5 / 11)$ を示し, 3 年生存率で は動注群 $57,1 \%$ (4/7), 対照群 $38.3 \%(5 / 13)$ という 結果で亦った。

すなわち，血管内侵入陽性，陰性のいづれの群にお いても動注群の方によりよい成績が得られている。 (図 17)

6）姑息手術成績

姑息手術と胃動注法を併用した症例は少なく,2年半
転移(一)群

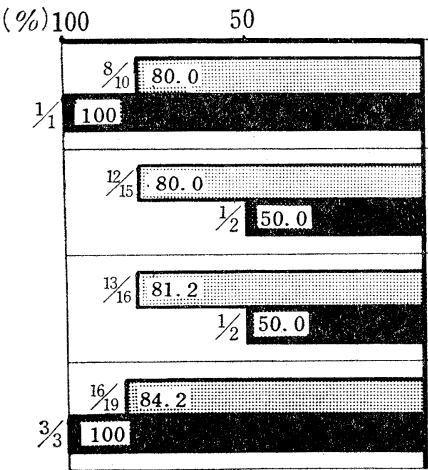

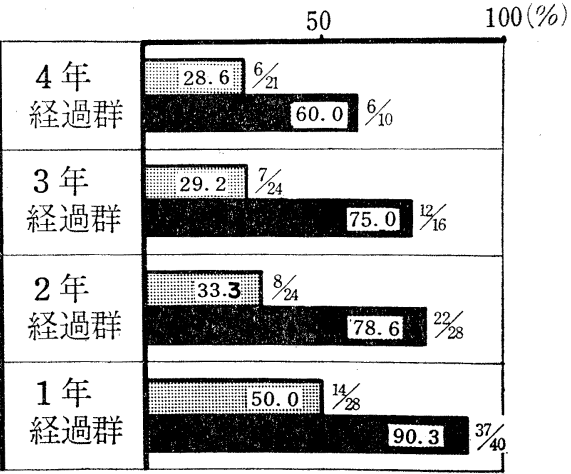

転移 $(+)$ 群 動注群

図16 リンパ節転移と治癒手術成績

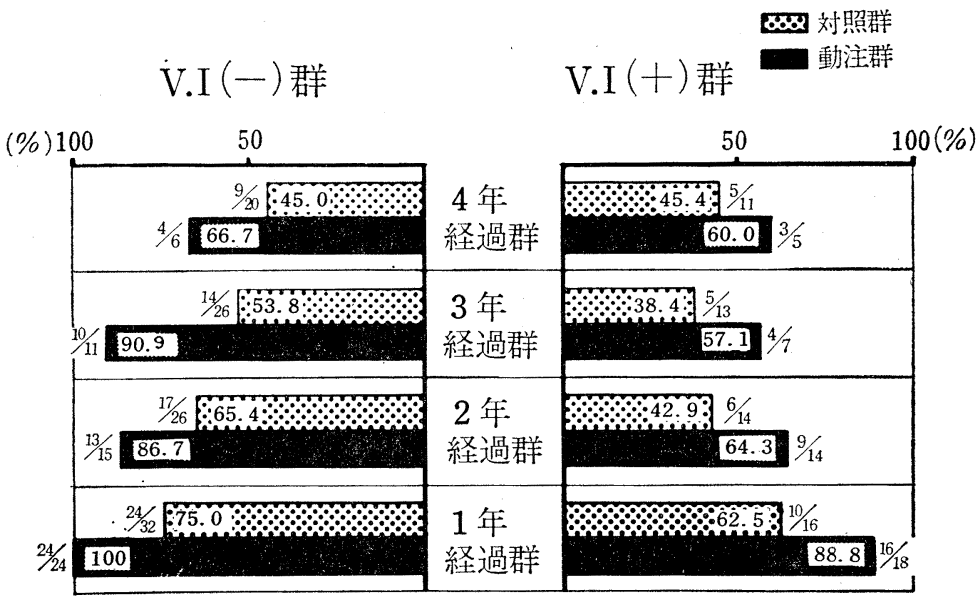

図17 血管内侵入と治癒手術成績 


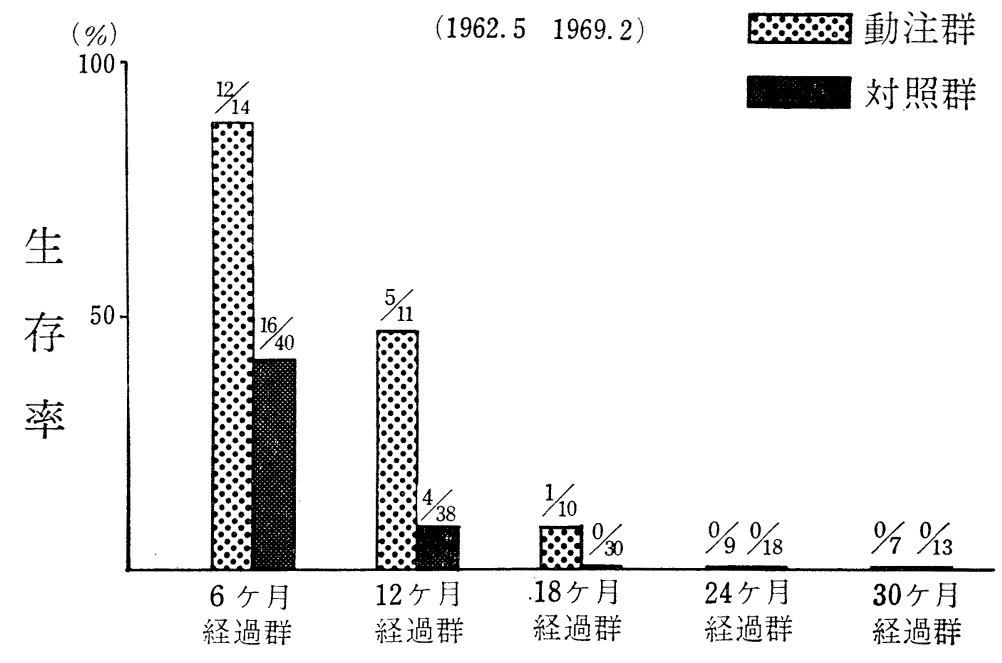

図18姑息手術成績

以上生存した症例は動注群, 対照群ともにみられな

い. 動注適用症例で 2 年以上経過例は10例あるが, そ のうち 1 例のみ 2 年 3 カ月の生存期間を得たに過ぎな い.

術後 2 年までの経過では, その存命期間が動注群の 方にやや長い傾向がみられているがいずれにしても長 期生存を期待するてとはできない.

\section{d）動注適用症例の副作用の検討}

1）血球成分の変動

耳架あるいは末梢血を早期空腹時棌血しその血球 成分の変動を測定したとてろ, 赤血球数は, $\mathrm{MMC} 10$ $\mathrm{mg}(0.2 \mathrm{mg} / \mathrm{kg})$ 及び $20 \mathrm{mg}(0.4 \mathrm{mg} / \mathrm{kg})$ 胃動注を 行った際に, 術前值の平均で約 $400 \times 10^{4} / \mathrm{cmm}$ である が，術直後は輸血などのために一定した值は示さない ものの10日後, 30 日後にはやはり約 $400 \times 10^{4} / \mathrm{cmm}$ で なだらかなカーブを示している。

白血球数は術後 2,3 日頃には増加するが, 術後 7 日以上を経過するとその平均值は $4,500 \sim 8,000 / \mathrm{cmm}$ 内での変動を示し, 特に術後白血球減少が一椂におて るというととは認められなかった。

栓球数は MMC $0.4 \mathrm{mg} / \mathrm{kg}$ 投与で一㥞汇術後 $3 \sim 6$ 日の間に減少傾向を示し， $10 \times 10^{4} / \mathrm{cmm}$ 以下になる 症例もみられるが，7 日頃より増加しはじめ，14日後 には添㴽術前值に回復してくる.（図19，20)

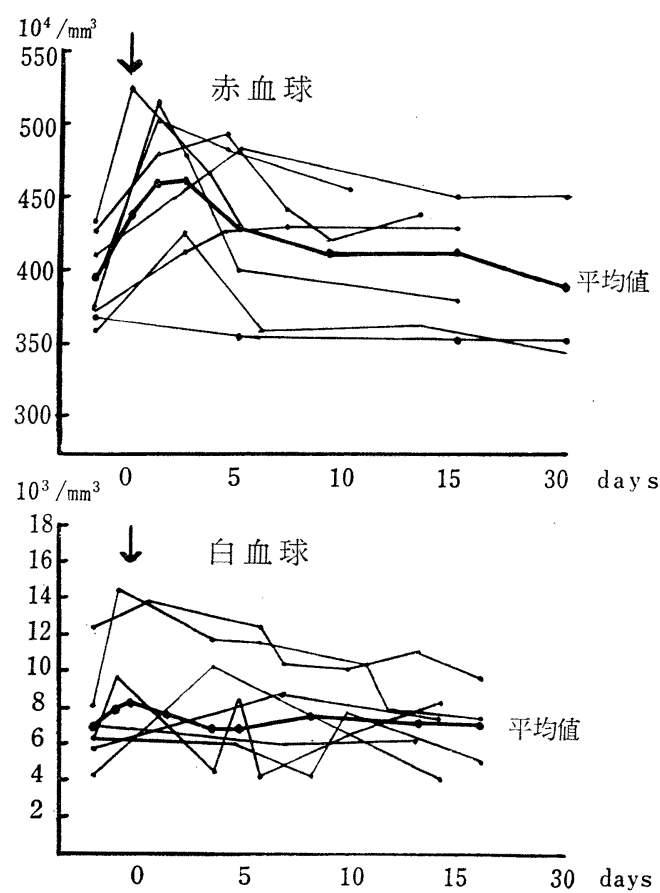

図19 血球成分の変動 [ $\mathrm{MMC} 10 \mathrm{mg}(20 \mathrm{\gamma} / \mathrm{ml})$ 動注 

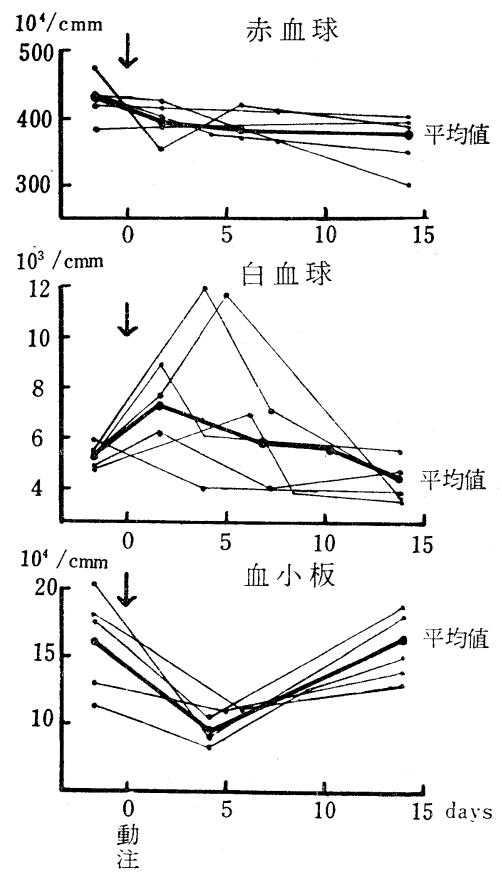

図20血球成分の変動〔 M M C 20mg $(40 \% / \mathrm{ml})$ 動注]

2）肝機能の変動

G.O.T. 值はMMC $0.2 \mathrm{mg} / \mathrm{kg}$ 投与群:で,術前から術 後にかけて 8〜40単位内での変動にとどまり， MMC $0.4 \mathrm{mg} / \mathrm{kg}$ 投与症例では術後 2 週以後に60単位以上を 示したものが 2 例あったが，その後の検査で正常值に
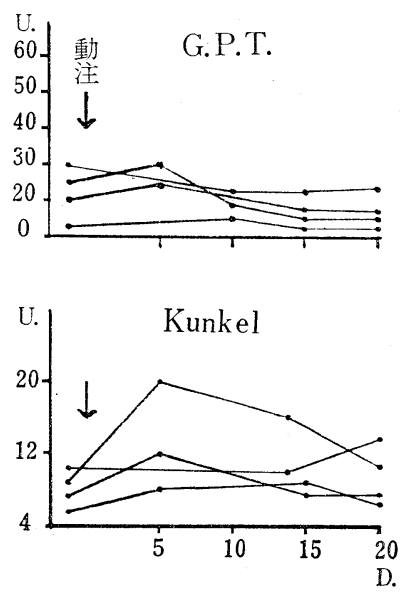

復した．大部分は，40単位以下の正常範囲内での変動 を示した. G.P.T.值はG. O.T.上昇症例でやはり 60 単位以上を示したが，乙れも 3 週後には40単位以下に 恢復し, その他の症例は $4 \sim 44$ 単位以内の変動を示す に過ぎなかった。

B.S.P. (30分值) はMMC $0.2 \mathrm{mg} / \mathrm{kg}$ 投与群で術後 5～15日頃に10～20\%と上昇した症例がみられたが， いずれも20日を過ぎると下降し正常值内に復した。

膠質反応T.T.T.試験は 1 例のみ術後に 7.0 単位を 示したが，大部分は0.5 3. 0単位内での変動を示すに 過ざなかった，Z.T.T.試験ではMMC $0.2 \mathrm{mg} / \mu \mathrm{g}$ 投 与例のうちで, 術後 5 〜 15 日にかけて20単位を示した ものがみられたが, 他のものは $2 \sim 15$ 単位の正常範囲 内での変動であった. 一般に術前やや高值を示したも のは幾分上昇傾向がみられるが，それも軽度一過性の 障害といってよく，中等度以上の肝障害を惹起した症 例は皆無であった（図21，22）

3) 網内系機能 (Congo red index)

Adler and Reimann ${ }^{9)}$ の方法で早期空腹時の患者 の一側肘静脈から $10 \mathrm{ml}$ の採血を行ない, その針を抜 きとらずに $1 \%$ 滅菌 Congo red 溶液を $0.2 \mathrm{ml} / \mathrm{kg}$ 静 注し, 注入後 4 分及び 60 分後に約 $5 \mathrm{ml}$ の血液を他側 肘静脈から採血して, 静置凝固させ, 上清を $540 \mathrm{~m} \mu$ の 波長で光電比色，濃度を測定した ${ }^{10)}$. 比色計は Erma N-5 型を用いた。

MMC $10 \mathrm{mg}$ 動注症例 8 例, MMC $20 \mathrm{mg}$ 動注症例 8 例及び対照例として胃切除のみを行なった10例につ いて, 術前, 術後 1 週, 3 週に Congo red Indexを
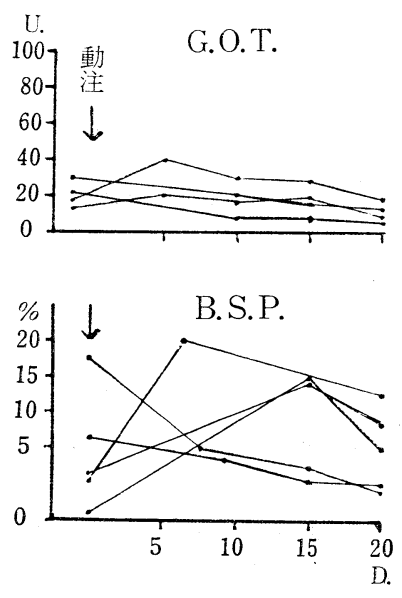

図21 肝機能 (MMC $10 \mathrm{mg}(20 \mathrm{\gamma} / \mathrm{ml})$ 動注] 
(566)

值 藤
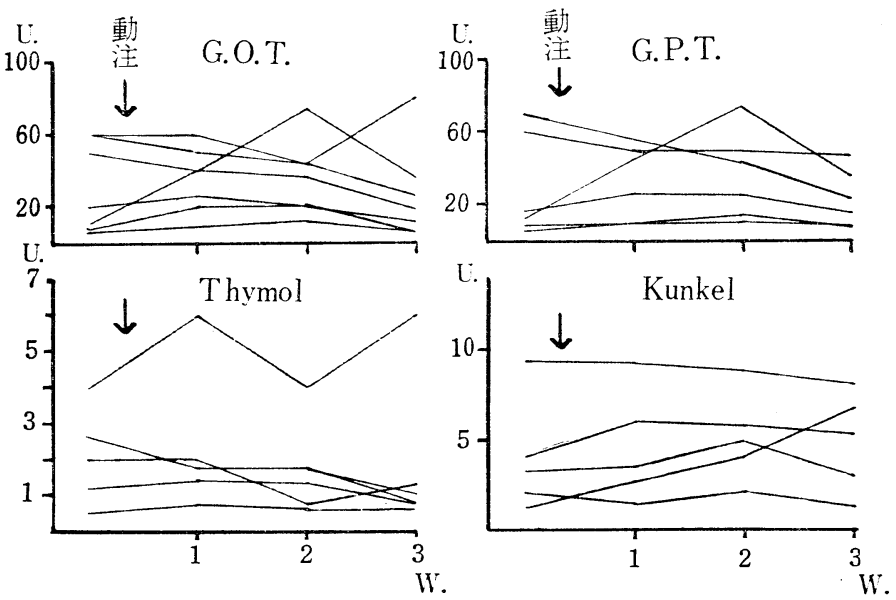

図22 肝機能 (MMC 20mg $(40 \mathrm{\gamma} / \mathrm{ml})$ 動注]

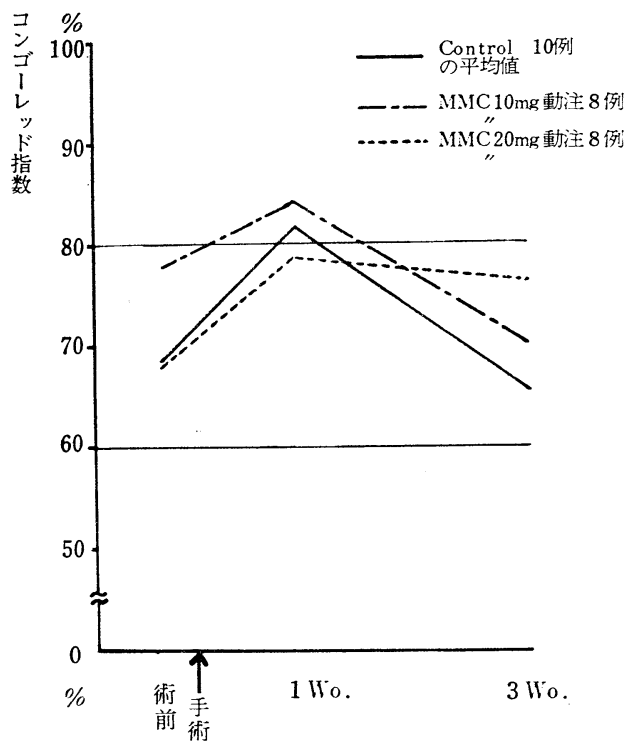

図23 網内系機能（コンゴーレッド指数）

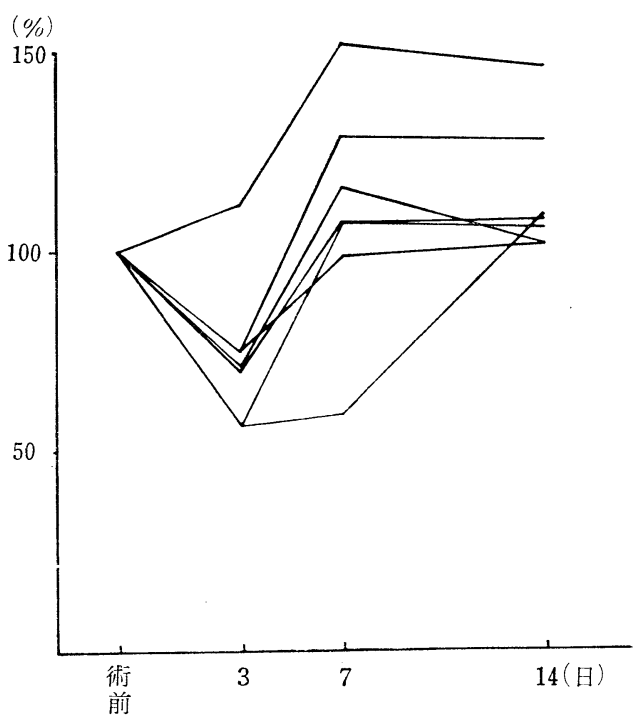

図24骨髄有核細胞数の変動（臨床例）

(術前值 $100 \%$ とする)

て, その有核細胞について術前, 術後值を比較した。 術前值を $100 \%$ とした場合に，術後 3 日では 50 ～70\% 々減少する症例が多く, 術後約 1 週頃から回復しはじ め術後 2 週では全症例とも術前值に回復した. (図24)

5）動注法副作用の小括

術中胃動注法を施行した80例のうち, 手術直接死亡 症例は 1 例であり, 直接死亡率1.25\%であった。乙れ は対照群の死亡率3. $82 \%(6 / 157)$ に比殡すると適用症 
例は少ないが，その直接死亡の危険性は低いものと考 えられる。

また，乙の直接死亡例も臨床病期は Stage N で non curative gastrectomy を行なった症例であり， 死因は縫合不全によるものではなく, 再開腹で痖着性 イレウスが碓認されたもので胃動注のために直接死亡 したとは考光難い。

MMC 動注症例で Agranulocytosis の如き重篤な 骨骫障害を若起した症例はないが, 術後 白血球数 $3000 / \mathrm{cmm}$ 以下になった症例が80例のうち 7 例あり, うち 6 例は術後の制癌剂投与を受けたもので, 投与中 止後 7 〜 10日で回復した. 対照例 157 のうちで, 術後 制癌剂の全身投与を受けたもの 5 例が 白血球数 $3000 / \mathrm{cmm}$ 以下になった。 白血球数 $4000 / \mathrm{cmm}$ 以下に なったものは, 動注症例17例, 対照例 9 例であってほ とんどは術後の制癌剤全身投与を受けた症例である が，動注例において特に回復の遅れるようなととはな かった. 術後10日以内に術前值より白血球数が減少し たものは動注症例で $15.0 \%(12 / 80)$ ，対照例 $5.1 \%$ （8/157）であり，動注例で高頻度を示した。

術後まもなく重篤な肝障害を示した症例はみられな かったが, 術後約 8 力月を経て蛋白尿, 尿円柱の出現 がみられたものが 2 例あった。手術創哆開, 出血傾 向，遷延性消化管出血などは動注例で特にみられなか った.

以上の如く，胃動注により重篤な副作用のみられた 症例はないが，一般的に軽度一過性の骨䯣機能低下を 示した症例は多かった。

\section{e）臨床症例のMMC末梢血中濃度}

臨床例の胃動注特に末梢静脈内にカテーテルを留置 して定時的に採血を行ない，宮村氏薄首カップ法でM MCの力価をbioassayした. 動注終了時に, 最高血中 濃度 $0.10 \sim 0.20 \mu \mathrm{g} / \mathrm{ml}$ 示すが, 以後漸減し動注開始 後60分ではすべて $0.08 \mu \mathrm{gml}$ 以下となり，3時間後に は血中より MMC を検出するてとはできなかった。 (図25)

\section{$\mathrm{V}$ 考按}

\section{a）制癌剂の局所投与}

制癌剤の効果を充分に発現させるためにはその有効 濃度を一定時間以上作用させ放ばならないが，全身投 与法では現在我々が使用できる制癌剂では腫瘍細胞の みならず健常細胞をも障害してしまうために，おのず から投与量が制限され，あまり満足すべき結果が得ら れていない．しかし全身投与にしても色々な種類の制 癌剂をたくみ組合せて，副作用をできるだけ少なく して効果を最大にあげられるように，種々工夫がなさ れている.

一方，てのような全身投与法の欠陷を補う意味で局 所投法が考案され，局所潅流法 ${ }^{14)}$ 局所動脈内注入法な ぞが試みられている。

局所動注法は，1949年 Bierman ${ }^{15)} ら か ゙ ゙$ 初めて発表し て以来, Klopp16), Sallivan ${ }^{17)}$, Berberio ${ }^{18), ~ B y ~ r o n ~}{ }^{19}$, Tucher20), Henske21), Espiner22), Engeset23), Skinner ${ }^{24)}$ らの報告がある。本邦においても，白羽25)，

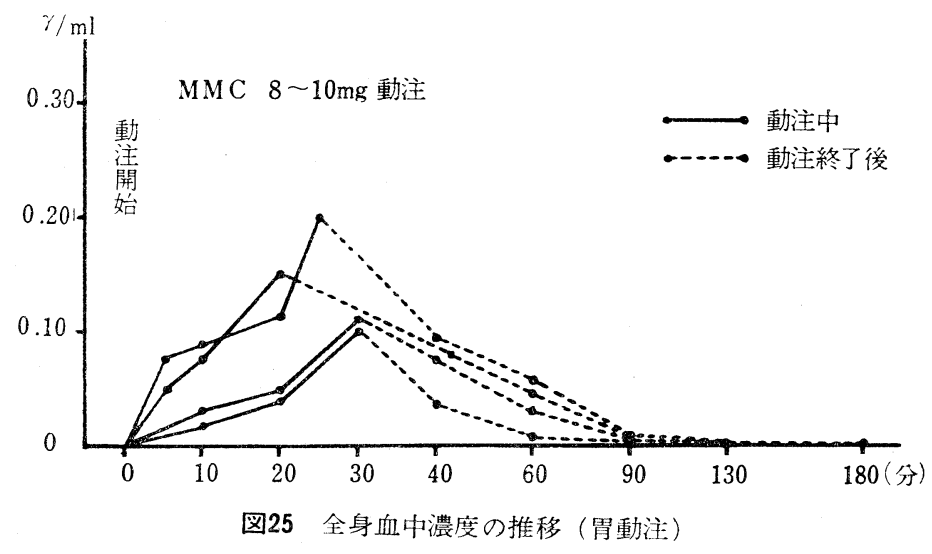


河村26), 井口27), 藤森 ${ }^{28}$, 伊藤29), 森田 ${ }^{30)}$ らの報告が なされている。乙れらは主として根治手術不能の末期 癌患者, 或は切除不可能な肝瀻癌などに用いられてき た.

b）使用制癌剂について

Alkylating Agents であるNMO, TESPAを初期 の臨床例の胃動注に用いたが，確かに抗腫瘍性は認め られるものの副作用か漒いので現在はほとんど使用し ていない.同じAIkylating AgentsであるCytoxan に関しても, 神前11 らが発表した如くての薬剤が肝細 胞を通過してはじめて活性化されるという点から胃動 脈内注入には不適当と考光使用していない，著者引は てれまで主としてMMCを $0.2 \sim 0.4 \mathrm{mg} / \mathrm{kg}$ 投与してき たが，近年 5-FUが容易に入手できるようになったの で, MMC と並んで臨床症例に対しても試跧的に胃動 注を行なった．ての5-FU12)は比較的他の薬剤か效か ない腺癌に対しても，すぐれ抗腫瘍性を示し，骨䯣系
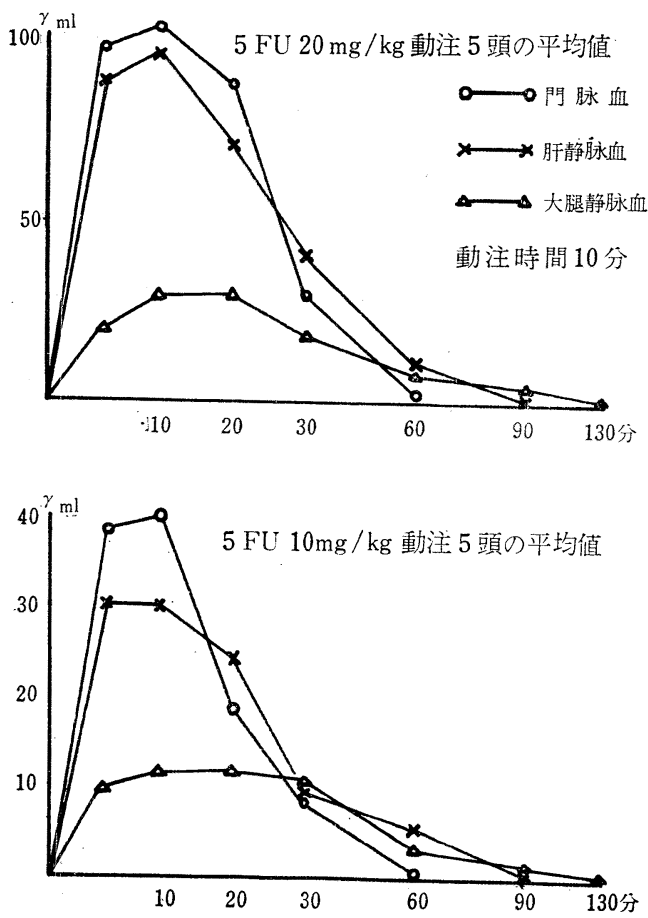

図26

動注实験における5 F U血叫濃度
に対する副作用発現率も他のもとのと比べて少ないと いわれているが，健康雑種成犬を用い胃動注モデル実 験を試みその血中濃度の推移を，Staphylococcus aureus $209 \mathrm{P}$ 株を用いて bjoassay したとてろ，M $\mathrm{MC}$ の場合と異って門脈血中濃度と肝静脈血中濃度と の間にあまり差が認められなかった。このととは Cが肝で不活性化されるととに原因があると思われ る. (図26)

この際の末梢血及び肝機能は， $5-\mathrm{FU} 10 \sim 20 \mathrm{mg} / \mathrm{kg}$ One shot 動注法では特に障害を認めることはでき なかった， MMC は秦13) によって開発され, 各抗腫 瘍性をもつ三つのグループ（キノン,ウレタン.アデリ ヂン）から成り，非常に強力な抗腫瘍性と広い抗腫瘍 スペクトラムをもった Antibiotics である。らせん 二重構造を有するDNAの塩基Cytosin, とGuanin の 間にCross linking して DNA 合成を阻害するてとに より強力な Cancericidal，actionをなすといわれて64， 約15分間の One shot 動注を行なう本法には最適の 薬凨と考える。

c) 手術と併用 (adjuvant chemotherapy)

手術と併用して制癌剤を使用する場合, その目的は あくまでも手術成績の向上であり, 再発を予防して, たとえ1\%でも成績の向上を意図するもので，adju－ vant chemotherapyによって手術直接死亡，あるい は術後合併症の增加をきたすてとは絶対に避けねばな らない。

手術と併用する制癌剤投与法を大別すると術前投与 法, 術後少量持続投与, 術後大量間歇投与及び術中大 量投与などがある.

術前投与法について：

Stöger ${ }^{31)}$ が Colchicin を術前 2 時間に使用したの が最初であろう。本邦でも陣内 ${ }^{22)}$ らは, MMC 各 $10 \mathrm{mg}$ を連日 4 日間全身投与後 $1 \sim 2$ 週で根治手術を施行す る方法を行なっている，佐藤33引は実験動物腫湟に Nitromin を術前に使用し, 腫瘍細胞転移の抑制をる て，乙れを原発巣における癌細胞間の結合力の増加の ためと考察している。

陣内 ${ }^{22)}$ らはその術前投与法について。癌細胞が $\mathrm{MM}$ $\mathrm{C}$ と接触すると集団塊となり血中に押出され難くなる こと, 切除標本で制癌剤の効果判定が， ある程度でき るとと, 制癌剤によっ崩壊した癌細胞が抗原として働 き，患者の癌比対する抵抗性が高まるのではないかと 
いう免疫学的可能性もあるととを利点として強調して いる。しかしながら，通常 $\mathrm{MMC}$ の副作用の顕著とな る投与後 $1 \sim 2$ 週雇大根治手術の大侵襲を加えるこ との是非，てのような投与量ではたして solidTumor に対して有效濃後が得られるかという疑問，また壆に 対して効果のない量を投与し続けるような場合に,

Adverse Effect という厄介な事態が発生しうるてと などいろいろの問題を残していると思う.

術後投与に関して :

術後投与についてはすでに多くの報告があるが.

Moore ${ }^{35)}$ らによれば術後少量継続投与法では $1 \sim 2$ 年 位は対照群と比べてやや良好な経過をとるが， 3 年位 では全く差がなくなり, 或はかえって成績が悪くなっ たと報告しており，その他の報告もまた，大体同様の 成績を示している。最近, 木村 ${ }^{36)}$ らは FAMT 療法と いう多剂併用法を考案して好結果を得たと報告してい

る. 確か化全身投与法は化学療法の定型的方式と思わ れるが，優れた制癌剤の発見されていない今日では， まだ允分な効果が得られないのが現状である.

術後間歇的投与について:

島田37)らは早くより制癌剤の間歇的投与の有用性を 主張しており， MMCの $4 \sim 6 \mathrm{mg}$ のまたは $8 \sim 10 \mathrm{mg}$ を週 2 回投与した群の他覚的所見の改善は, $1 \sim 2 \mathrm{mg}$ 連日静注群に比べて顕著であると報告している。

術後大量衝撃投与について:

坪井38)らは MMC $1 \mathrm{mg} / \mathrm{kg}$ の大量を術後 One shot で静脈内に投与した後, 中和剤として, チオ硫酸ソ一
ダを使用して副作用を軽減するMMC 大量衝撃療法を 試みている。

著者もハイポの制癌郕仁刘する拮抗性の有無を検討 すべく実験を行なったが，MMCに対してハイポは in vitro, in vivo ともに中和作用を想めることはで きなかったので，臨床的に使用していない（図27, 28, 29)

神前39) ら 内投与を行なって，胃癌の Stage II のものに効果が あったとし, 漿膜浸潤の強いものには無効であり, こ のような症例付対しては MMC の腹腔内大量投与法を 行なった。

てのように制癌剂の術後投与殊に本邦では胃癌の術 後投与に対して種々の工夫がなされ，ある程度の効果 が報告されて 40)・43)いるか,てできれば可能な限り長期 間の投与が望ましい訳で，どうすれば術後長期にわた って制癌剂を投与できうるかが，今後我々亿残された 大きな課題であ万う. 術後投与の多くの成績が術後 1 〜 年は制癌剤投与群の方がよいが， 3 年を過ざると 対照例と大差なくなるというのも或いは術後の制癌剤 の投与期間とも関係しているかも知れない.

術中投与法について :

術中投与については, 服部らの 44$)$ (6) 骨髄移植とM $\mathrm{MC}$ 術中大量静脈内投与法之の併用, 井口47)らの腹部 大動脈を腎動脈分岐部より末梢側で一時的に遮断しな がら制癌骫を上腕静脈より投与する方法が報告されて いるが, 経静脈的に投与するという点に有効濃度およ

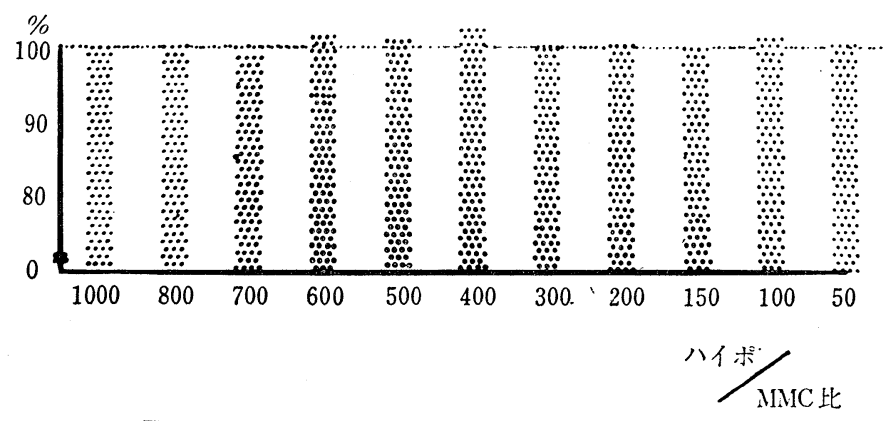

図27 MMC々八イポの中和䒠験 (in vitro) 


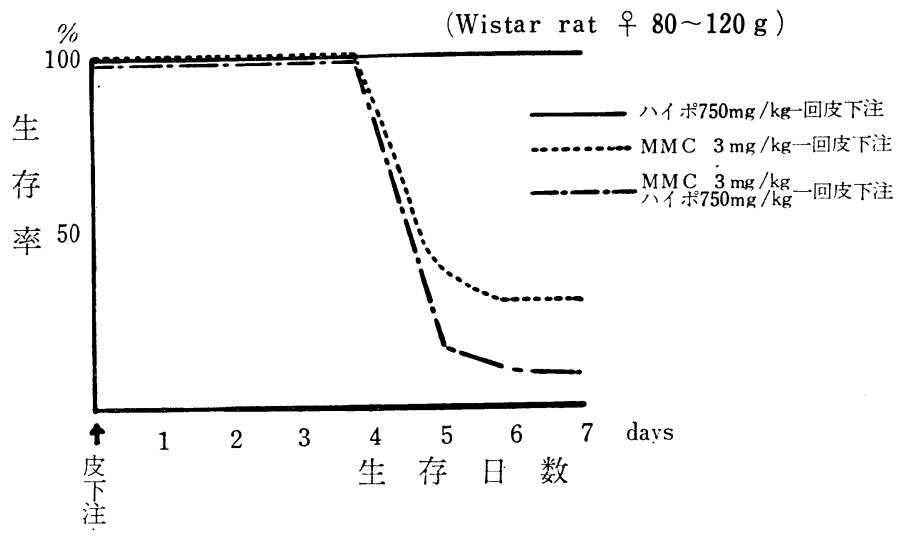

図28 MMCとハイポの中和実験（in vivo）
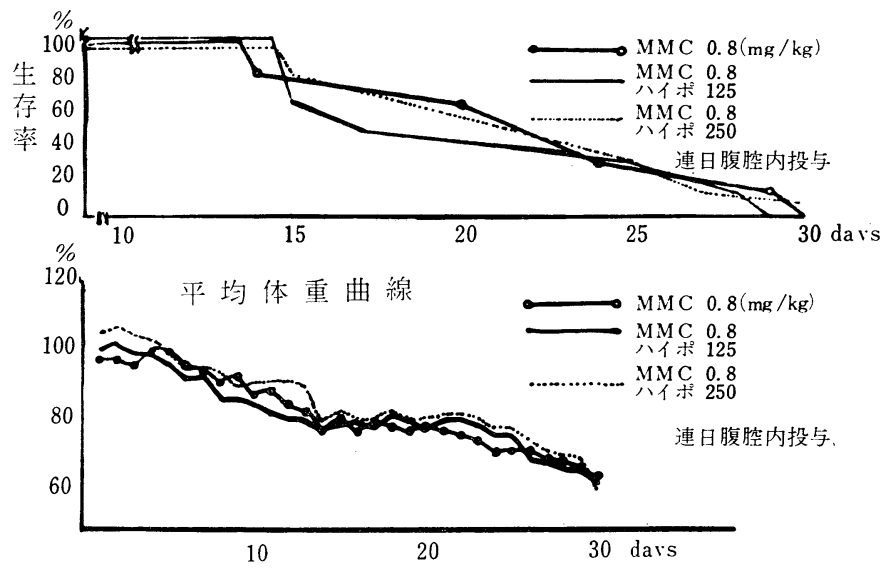

図29 MMCと八イポの中和実験（in vivo）

び全身の副作用と関連して難点がある．砂田48)らは術 中腎動脈分岐部より末梢側を 5 分間圧迫して, 直接大 動脈内にMMC $02 \sim 02 \sim 03 \mathrm{mg} / \mathrm{kg}$ と穿刺注入して いるが，乙れまたMMCのほとんどが豎動脈内に流人 し，MMCに sensitiveな腎上皮細胞に作用したり， 高濃度のものが全身血中に移行し, かつ胃動脈内にさ ほどの有効血中濃度が得られないのではないかと危惧 される。また今永 ${ }^{49)}$ らは術後の肝転移防止の意味で術 中肝動脈に制癌剤を穿刺注入しているが，穿刺部位の 選択などの手技上の問題があると思われる。

著者らはでるるだけ少量の制癌剤で大きい効果が得
られるように独特の胃動脈注入法を考案し、朋転移, 局所再発防止の抑制に努めている。

d）胃動注法の理諭と根拠

実際に胃切除を行なう場合に, 癌腫に対して機械的 刺激を全く避けるととは困難であって, 浸潤範囲を知 るための直接的な外力のほかに率引, 圧迫などによる 間接的外力が加わって癌細胞が癌腫より剝脱したり, 血管内に侵入していた癌細胞を更に撒布する可能性が 当然考えられる. 斯稼な問題を解決するために手術操 作洗だって胃局所血管の結禁を行なうことが考えら れるが，胃癌に関する限りこれのみでは不完全であろ 
う. 腫瘤に近い血管の結紮は, 腫瘤への機械的刺激が 避け難いし, 左右胃動静脈, 左右胃大緰動脈を結紮し ても．胃壁粘膜下における豊富な血管網のために残存 する短胃動静脈へ癌細胞の流出する可能性も考えられ るからである.

癌患者の流血中に癌細胞50) 55) が出現し. 殊に手術 操作に伴なって増加するという報告はかなりみられる が，血中癌細胞の同定についてはなおも種々の問題が 残されている.

また, 癌細胞の血管内侵入像を認めるもの注，遠隔 転移も多く予後も悪い，功な細胞播種，転移形成 の予防法として

（1）癌病巣に対する機械的刺激をできるだけ避 けるとと。

（2）手術操作に先行する局所血管の結禁

（3）術前, 術中, 術後の化学療法の併用

(4) 術前放射線照射等が試みられている.

しかし術前照射は胃癌が比較的放射線に対する感受 性に乏しく. 効果を得るような大量照射を行なうと， 全身への副作用のため状態を㤟くすることは避计難く 実用化には問題がある。Che notherapy を併用する 場合，その薬剤が決定したら，その使用法が問題とな るが, 従来の如き静注全身投与法では好ましくない結 果になる場合があることは前述の如くである。

Miller ${ }^{56)}$ Economon ${ }^{57)}$, 米本 ${ }^{58)}$, Brennen ${ }^{59)}$, 白羽 ${ }^{60)}$ らは既代形成された肝転移位しては，上り酸素分圧 の高い肝動脈経路からの制癌剂投与が有効で, 腹腔内 諸藏器の術後の転移形成予防には術中門脈系江投与す る方がより有効であると報告している。

制癌剂を門脈㲸注入して, 門脈内の有效濃度を維持 するには, 内脈血流量からいって大量の制癌剤を心要 とするが，既に実駼編で述べたでとく，直接胃動脈内 に投与すれば比較的少量で局所濃度を有效濃度に保つ てとができる，また，門脈本幹から肝に流入する制癌 剤は豊富な閒脈血によって稀釈され，肝障害を防ぐて とにもなり，殊にMMC は肝細胞で不活化されるため に, 全身血中濃度は比較的低濃度に保てるので重篤な 骨髄系障害は免れ得るのではないかと考えた，以上の 観点加著者は, 胃癌手術に対する抗癌剤の最も有効 な併用療法として, 胃癌根治手術中に胃動脈内一制癌 㑉を注入する方法を試みたのである。

大塚61)は 動注症例の胃癌組織の核酸代謝を検討し
て, DNA 分画へのC14-のとりてみ率は, 対照群と比 べ抑制されるとし, 馬場62)は動注症例の胃癌組織を電 子顕微鏡下に観察して, 核の構造力㵇れ, Mitochondria が円くなり，Cristae のほとんど消失した如く みえるとしているが，いずれも本法の有効性をある程 度実証していると思われる。

e）胃動注適用症例の治癒手続成績䎲関する考 察

臨床病期別にみた治瘾手術成績について, Stage I では動注症例が僅か3 例なので比較できなかったが， Stage II $の 4$ 年以上経過群では推計学的有意差をもっ て動注群の成續がよく, Stage III でも 1，2，3 年以 上経過群までは動注群が推計学的有意差をもって優れ た成績を示した，深達度別にみた場合に，漿膜浸潤の あるss, $\mathrm{s}$ 群では, 1 年, 2 年以上経過群までは有意 差をもって動注群が優れているが, 3 年, 4 年以上の ものには症例が少なく推計学的有意差を認め得なかっ た.

ss，s 群では年を経過するにつれて, 動注群と対照 群との差分縮まってくる傾向にあり，漿膜浸潤のある 胃癌の手術成績问上にはさらに一考を要するものと思 われる。リンパ節転移陽性例については，1，2，3 年以上経過群までは有意差をもって動注群の成績が良 好であった。

血管内侵入陽性群では一応動注群の方が優れた成績 を残しているものの，3，4 年以上経過群では症例数 が少ないためか推計学的有意差を認めるととはできな かった。

この傾向はリンパ管内侵入症例でも同様であり, 組 織像についても動注群と対照群を比較したが，腺癌あ るいは単純癌など組織型や, 粘液産生能. 間質量, 浸 潤度などてついても持記すべき両群の差を默めるてと はできなかった。

\section{VI 結 語}

すでに多くの報告にみられるように，根治不能の胃 癌に対して化学療法を施行しても, その大部分は一時 的効果しか期待し得なかった事実を顧みて，著者は現 段階化扔ける制癌剤の最も有効な使用方法は根治手術 に併用する局所投与法であろうと考光，その一つの試 みとして胃癌の根治手術中の胃動脈内制癌剤動注法に 
関する研究を行なった

\section{動物害験編}

1）色菜を左胃動脈より注入するに際して左胃静脈 遮断に短胃動脈以外の動脈を遮断する場合が最も広笨 囲にしかも低圧で注入できた。

2） $\mathrm{MMC} 20 \mu \mathrm{g} / \mathrm{ml}$ 年10間接触した腹水肝癌 $\mathrm{AH}$ 7974 を脾内に注入しても, 肝転移及び腹水癌の発生は 認めなかった．MMC $20 \mu \mathrm{g} / \mathrm{ml}$ は腫瘍の転移を抑制す る最低濃度と考えた。

3）局所及び全身の副作用からみた $\mathrm{MMC} の$ 最高許 容濃度は $80 \mu \mathrm{g} / \mathrm{ml}$ で，乙の濃度以下の適用が臨床症例 にとって望ましい.

4）胃動注実験で，MMC $06 \mathrm{mg} / \mathrm{kg}$ を注入した際 に, 門脈血中濃度は最高值 $1.10 \mu \mathrm{g} / \mathrm{ml}$ ⿸示し, 才腿静 眽血中濃度は最高値 $0.23 \mu \mathrm{g} / \mathrm{ml}$ を示した。

いずれの例でも動注後 2 時間には大腿静脈から $\mathrm{MM}$ Cを検出できなかった。

臨床編 :

5）胃動注法を施した80例を検討し，そのうち治療 手術後 4 年以上経過したものは少数例であるが，その 4 年生存率は63.6\% (7/11) であり, 対照群は $38.9 \%$ (14/31) である。

6）臨床病期別訹後成績をみると Stage II,

Stage III の3 年生存率は，動注群それぞれ $77.7 \%$ (7/9), 55.6\% (5/9) であり，対照群ではそれぞれ $40.0 \%(6 / 15), 23.1 \%(3 / 13)$ であって推計学的有意差 をもって動注群が良好な成績を示した。

7）リンパ節転移陽性のものの術後 3 年生存率は動 注群で75.0\%(12/16), 対照群で29.2\%(9/24) あって 推計学的有意差をもって動注群が優れている.

8）姑息手術例に制癌制動注法を合併した症例に は， 2 年 6 ケ月以上の長期生存例はみられなかった.

9）臨床症例 80 例のうち手術直接死亡は 1 例で, 死 因は縫合不全ではなく胃動注のため直接死亡したとは 考光難い.

10）臨床症例のうち骨膸系及び肝腎機能に重篤な障 害を示した症例はなかった。

従って, 胃動注法は比較的少量の制癌剂で局所濃度 有效濃度に保ち, 胃癌心再発应抑制し, あ万程度谁 行した胃癌の予後を改善できるという点で, 試みるべ き方法と考える,
稿を終るに臨み、御指導御校閲を賜った恩師藤森汇 雄教授に深甚の謝意を捧げるとともに御指導御協力下 さった坂内五郎教授、鈴木 茂講師に衰心から感謝 し、併せて種々御協力御助学いただいた故阿部千秋, 故貞光 䒧。川井忠和, 塩崎秀郎, 馵場憲臣、北条靖 ほか教室諸兄，また定験に終始御協力下さった医学部

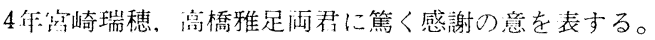

\section{VII 文献}

1）梶谷 鐶他: 綜合医学, $18: 457-467,1961$.

2）村上忠重他：外科揨療，7(6)：647-655, 1965 .

3) 中尾行保他: 手術21 (4) : 396-404, 1967.

4) 第 6 回癌治療学会総会特別展示, 1968.

5）陣内伝之助: 外科, 23(11)：1009-1107, 昭和36.

6）胃癌研究会編：外科, 病理胃癌取扳い規約, 金原 出版, 1966 .

7）原田雄次郎：マイトマイシン基礎交献集（協和䣫 酵)，120，1960.

8）舜村定男 : J. Antibiot. Ser. B., $16: 251$, 1961.

9) Adler, H . und Reimann, F. : Zschr. experi. med., $47:$ 617-633, 1925.

10）山形献一他: 最新医学, 17(5):1065-1074, 昭和 37.

11）神前五郎他 : 癌の臨床別冊（癌の化学療法） 7394 , 医南薬出版社, 1966.

12）5-Fluolouracil，1-22, 協和醴酔， 1966.

13) Heidelberger, C. : Cancer Research, 18 : 672, 1958.

14) Creech, O. : Ann. Surg., 148:616, 1958.

15) Blerman H. R. : California. M. center, $1: 84,1949$.

16) Klopp, , G. T. et al. : Ann. Surg., 132 : 811, 1950.

17) Sullivan, R. D. et al. : Cancer, $6: 121$, 1953.

18) Berberio, J. R. : Cancer, $4: 1341,1951$.

19) Byron, R. L. et al. : Surg., $45: 634,1959$.

20) Tucher, J. L. : Cancer, $14: 493,1961$.

21) Henske U, K, : Intern, Abst, Surg, , 112 : 
$513,1961$.

22) Espiner, H. J. : Lancet, 1177, 1962.

24) Skinner, O. B. : S. G. O., $115: 242,1962$.

25）白羽弥右衛門: 癌の臨床, $2: 534,1956$.

26）河村, 服部他：日多会誌，57(5)：788，1956.

27）井口潔: 手術, $16: 601,1962$.

28) 藤森正雄他: 第49回日本消化器病学会発表. 1963.

29）伊藤一二他：癌の臨床. 10(5) : 412, 1964.

30）森田 茂他：癌の臨床, 8(12): 772, 1962.

31) Stöger, R. : Arch. Geschwul. Forsch., 5 : $252,1953$.

32）陣内伝之助 : 癌の臨床, 8(9) : 533, 1962.

33）传藤 伝他：臨床外科, 18(1): 30, 1963.

34) 今永一：臨床と研究, $38: 205,1961$.

35) Moore, G. E. : Cancer, $13: 111,1960$.

36）木村禧代二他：第22回日本癌学会記事1：1,1963.

37）島田信勝他: Chemotherapy, $10: 290,1967$.

38）坪井重雄 : 癌の臨床, 13(3): 166, 1967.

39）神前五郎他：外科治箮，6:595，1962.

40）芝茂：日外会誌，67(9)：1579，1966.

41）德山英太郎：外科治療, 6(5): 50, 1962.

42）大森幸夫 : 癌の臨床, $11: 361,1965$.

43）星野智雄 : 癌の臨床, $11: 361,1965$.

44) 服部孝雄 : 癌の臨床, $6: 346,1960$.

45）服部孝雄 : 癌の臨床, $7: 232,1961$.

46）服部孝雄 : 癌の臨床, 10(2) : 96, 1964
47）井口 潔 : 癌の臨床, 11(3)：142, 1965.

48）砂田輝武他：癌の臨床別冊（癌, 化学療法) 203216 , 医歯薬出版社, 1966.

49）今泉 一他: 第68回日本外科学会発表, 1968.

50) Robert, S. et al. : Cancer, $15: 231,1962$.

51) Soriggs, A. I. et al. : Proc. Roy. Soc. Med., $53: 169,1960$.

52）遠藤辰一郎他：外科, 26(1) : 51-58, 1965.

53) Engell, H. C. : Acta chir. Scand, 1:201, 1955.

54）田崎 勇: 綜合臨床, $9: 549$, 昭35.

55）間島 進: 第20回日本癌学会記事，16, 昭36.

56) Miller, J. R. : A. M. A. Arch. of Surg., $82: 423,1961$.

57) Economon S. C. et al. : The surg. Clin. of North America, $42: 1147,1962$.

58) 米本 博 : 第63回日本外科学会発表, 1962.

59) Brennen, M. J. : Ann. Surg. $158: 465$, 1963.

60) 白羽他: 癌の臨床, $6: 493,1950$.

61) 大塚浩之: 北関東医学. 18:304-313. 昭 43 .

62）馬場憲臣: 第52回日长消化器病学会発表. 1966.

63）久留 勝監修: 腫瘍生化学, 朝倉書店, 592, 昭 40.

64）芝茂編：マイトマイシンの基礎之臨床，97101, 医学書院, 1967. 


\title{
RADICAL GASTRECTOMY COMBINED WITH GASTRIC ARTERIAL INFUSION OF ANTI-CANCER AGENTS
}

\author{
KAZUNORI SATO \\ Department of Surgery, Gunma University School of Medicine, \\ Maebashi, Japan \\ (Director : Prof Masao Fujimori) ?
}

The operation is the best therapy of stmach cancer. 5-year suvival rates, however, have not reached $50 \%$ in any report, so we feel urged to additive treatment of this disease. Manuplation of surgery increases cancer cells in blood, causing recurrence of carcinoma, so as latent liver metastasis, vascular invasion, intramural metastasis and serosa infiltration.

Since 1962, we have tried gastric arterial infusion of antj-cancer agents during radical operation, as to decrease recurrent stomach cancer.

Our method based on the laboratory data of model experiment of which results were as follows.

1) When Mitomycin C was administrated into left gastric artery, we obtained the broadest infusion area in case that left gastric vein and the other gastric artery had been ligated except short gastric artries.

2) Wistar rats were prevented from liver metastasis, when $\mathrm{AH} 7974$ had come in contact with Mytomycin $\mathrm{C} 20 \mu \mathrm{m} / \mathrm{ml}$ and administrated into rat spleen.

3) Mitomycin $\mathrm{C}$ more than $80 \mu \mathrm{g} / \mathrm{ml}$ brought side effect to male mongrel dogs. We have indicated this method to 80 clinical cases, including one patient dead postoperatively within one month; cause of death was proved to be acute cardiac failure in course of intestinal obstruction.

No patient died because of chemotherapeutic complication : agranulocytosis and so on. 58 patients were treated by curative gastrectomy combined with arterial infusion. $63.6 \%(7 / 11)$ is 4-year survival rate of this group, while $38.9 \%(14 / 31)$ of control group, namely patients group treated by only curative gastrectomy.

It can be seen from the above that radical gastrectomy combined with gastric arterial infusion have noticeable effect to stomach cancer. 